\title{
Globalization and Electoral Outcomes: Evidence from Italy*
}

\author{
Mauro Caselli ${ }^{\dagger \ddagger} \quad$ Andrea Fracasso Silvio Traverso $^{\mathbb{1}}$
}

June 7, 2019

\begin{abstract}
We study whether and to what extent the electoral dynamics in Italy over the 19942008 period can be explained by the development of economic factors associated with globalization. To measure the level of exposure to globalization for local labor markets, our main unit of analysis, we use the intensity of import competition from China and the presence of immigrants. Looking at parties' political positions and employing an estimation strategy that accounts for endogeneity and time-invariant unobserved effects across local labor markets, we find that both immigration intensity and exposure to import competition from China have contributed positively to the electoral outcomes of far-right parties, whereas only immigration intensity has increased the vote shares of right-wing and traditionalist/authoritarian/nationalist parties. Some evidence, albeit not robust, shows that immigration may have also had a positive impact on far-left parties, thus possibly further contributing toward political polarization. Moreover, electoral turnout has responded negatively to an increased presence of migrants. While the above effects seem to work through the mediation of labor markets, our results, especially those related to immigration, suggest that other mechanisms at the level of local communities are also at play. Keywords: voting, electoral outcomes, trade, import competition, immigration, local labor markets.

JEL Classification Codes: D72, F14, F60.
\end{abstract}

*The data that support the findings of this study are available from the corresponding author upon reasonable request. Financial support received through the project "Cambiamento istituzionale, crescita economica e sviluppo sociale", funded by the Autonomous Province of Trento (Italy) is gratefully acknowledged. We also thank Antonio Accetturo, Paolo Barbieri, Manuela Caiani, Italo Colantone, Stefano Comino, Guido De Blasio, David Dorn, Clara Graziano, Manuela Moschella, Francesco Nicoli, Stefani Scherer, Adrian Wood, conference participants at 2018 SETC, 2018 ETSG Conference, 2018 SIE, seminar participants at the Center for Social Inequality Studies at the University of Trento, the Department of Economics and Management at the University of Udine and the SNS workshop "Domestic Politics and Global Economics: From Policy Convergence to the Rise of Populism", and two anonymous reviewers for all their comments. The authors are solely responsible for any remaining errors.

${ }^{\dagger}$ School of International Studies, University of Trento, Italy.

$\ddagger$ Corresponding author, email: mauro.caselli@unitn.it.

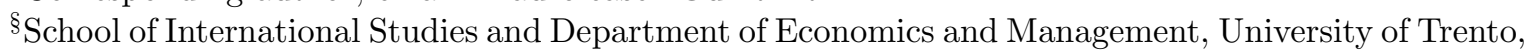
Italy.

${ }^{\mathbb{I}}$ School of International Studies, University of Trento, Italy. 


\section{Introduction}

The political landscape of Western liberal democracies in the last twenty years has undergone a substantial metamorphosis. New political actors have come to the limelight and the rhetoric and the contents of the political debate have become increasingly polarized. The success of populist, nationalist and anti-establishment parties characterizing the most recent period is only the latest evidence of a long-lasting trend whereby some of the founding principles of post-war Western international politics have been put more and more often into question, with a strategy that has progressively become electorally rewarding.

The theoretical and empirical literature that that tries to understand and identify the determinants of such political developments is broad and fast-growing. According to some scholars, these determinants should be primarily sought in the emergence of globalization, which may have increased the demand for both economic and 'cultural' protectionism (Hooghe and Marks, 2018; Kriesi et al., 2006; Margalit, 2011,1; Walter, 2017). ${ }^{1}$ Indeed, even though greater integration with the world economy has increased overall growth opportunities for all the countries involved (Bordo and Rousseau, 2012; Wacziarg and Welch, 2008), it has also acted as a catalyst for non-neutral structural changes that have triggered, within each country, political and social tensions (Beladi et al., 2018; Burgoon, 2012; Hanson et al., 2007; Rehm, 2009; Scheve and Slaughter, 2004; Walter, 2010). For example, the lowering of trade barriers towards low-wage countries may have adversely affected the workers of industries in developed economies enjoying, until then, a comparative advantage (Autor et al., 2014). On a more general level, globalization, as well as the concomitant (and possibly related) technological progress, might have altered the relative remuneration of different types of workers according to their individual endowment of human capital and skills (Helpman et al., 2010; Mayda and Rodrik, 2005; Walter, 2017). Likewise, the increasing presence of foreign-born citizens may

\footnotetext{
${ }^{1}$ In this work we shall not take a position on the alternative interpretations offered by (Kriesi et al., 2006), on the one hand, and (Hooghe and Marks, 2018), on the other, regarding the type of societal division associated with globalization.
} 
have tightened the competition in local labor markets and may also have triggered a sense of insecurity among natives, who may feel apprehension, inter alia, for the integrity of their cultural identity (Hainmueller and Hiscox, 2010; Hainmueller and Hopkins, 2014). ${ }^{2}$ Because of the asymmetric nature of the gains and the costs of globalization, diffuse and elusive the former while relatively concentrated and easily identifiable the latter, ${ }^{3}$ such tensions may have exacerbated existing societal divisions through various mechanisms. ${ }^{4}$ This, in turn, has translated into a gradually more explicit questioning of the founding ideas at the basis of the post-war Western international liberal order.

This paper aims to contribute to this growing literature by assessing the impact of globalization on the electoral outcomes in Italy over the 1994-2008 period, thereby extending this line of research to one of the largest and most trade-oriented industrialized countries among the Western liberal democracies. Italy represents an interesting object of research not only because of its engagement into the international trade and migration networks, but also because of its political environment characterized by a plethora of changing and diversified political parties with non-overlapping manifestos and frequent general elections (due to the premature end of a few legislatures). ${ }^{5}$ The empirical analysis is based on a panel containing electoral and socio-economic data on Italian municipalities. Consistently with the existing literature, local labor markets (defined on the basis of residents' commuting patterns) are employed as the main analytical units. The analysis, in a nutshell, focuses on the pre-crisis period and tackles whether and to what extent,

\footnotetext{
${ }^{2}$ In a parallel line of research on the relationship between globalization and democracy, Bearce and Hutnick (2014) find that immigrants from low-income countries tend to hinder the democratization of political regimes because immigration increases inequality and the associated redistributive efforts that greater democratization would call for.

${ }^{3}$ Moreover, in the case of immigration, part of the benefits is enjoyed by a group of people - the migrants - who usually have little, if any, political power in the destination country.

${ }^{4}$ The current debate is not entirely new and in the 1990s several scholars analyzed the contribution of globalisation to the economic, social and political developments in advanced countries. Yet, theoretical and empirical researchers at the time concluded by minimizing the role of globalization and emphasizing rather that of skill-biased technological change. As pointed out by Wood (2018), this was due to the overwhelming role played by the Heckscher-Ohlin trade theory in the interpretation of the potential effects of globalization on advanced countries. Empirically, moreover, the process had still to display its entire potential which became instead apparent after China joined the WTO and the Central and Eastern European countries became members of the EU.

${ }^{5}$ Between 1994 and 2008, there have been five parliamentary national elections, three won by the center-right coalition and two by the center-left coalition.
} 
once controlling for a number of socio-economic controls, the evolution of local electoral outcomes at the general elections in 1994, 2001, 2006, and 2008 can be explained in terms of meaningful proxies for the level of 'local exposure to globalization', i.e., the presence of immigrants and the intensity of import competition from China. In terms of electoral outcomes, the analysis considers the percentage of votes for different aggregations of parties based on their political positions, rather than the internally highly differentiated coalitions in which they run. Specifically, the paper studies the effects of globalization on the extreme right, the extreme left, right-wing parties and parties with a conservative stance on social issues, thus looking at both the traditional left-right divide and the new green/alternative/libertarian-traditional/authoritarian/nationalist cleavage. These political aggregations may overlap (i.e., they are not mutually exclusive) and the mix of parties composing them may vary over time based on changes in parties' political positions. To account for time-invariant unobserved effects across local labor markets, the analysis makes use of two baseline empirical models, that is a mixed first-difference model for the periods 1994-2001 and 2001-2008 and a fixed effects model for the years 2001, 2006 and 2008, that provide qualitatively similar results.

As a preview of some of the main findings, the estimates suggest that, over the period covered by the study, globalization has indeed played a role in shaping, at the local level, the outcomes of Italian general elections. Overall, both exposure to import competition from China and immigration intensity appear to have contributed to the electoral success of Italian far-right parties, whereas only the latter has produced a positive effect on the votes for right-wing and TAN parties. Among the other results, immigration seems to have had a positive, albeit not robust, effect on the electoral performances of far-left parties, whereas the electoral turnout has responded negatively to local increases in the presence of migrants. These results are robust to controlling for problems of endogeneity, which we address following the approach developed by Autor et al. (2013) for import competition and Otto and Steinhardt (2014) for immigration. Finally, while we hypothesise that labor market dynamics are the main channel through which the above mentioned 
effects work, we observe that the results, especially those regarding immigration, become stronger using municipalities as the unit of analysis, while they weaken bringing the analysis at the province level. These additional results suggest that some of the transmission channels that link globalization shocks to electoral outcomes operate within communities narrower than local labor markets. Such transmission channels are possibly related to the cultural-identity backlash against multiculturalism, as pointed out by Betz (1994); Inglehart and Norris (2016); Margalit (2012), or the impact of immigration on segregation patterns and housing prices in urban areas, as shown by Accetturo et al. (2014) for the case of Italy.

In light of the subject and the methodology adopted, the paper contributes to the recent strand of the political economy literature which investigates the globalization-related socio-economic determinants of electoral outcomes in Western liberal democracies (Autor et al., 2016; Barone et al., 2016; Che et al., 2016; Colantone and Stanig, 2018a,1; Dippel et al., 2017; Feigenbaum and Hall, 2015; Halla et al., 2017; Jensen et al., 2017; Malgouyres, 2017; Rommel and Walter, 2018). ${ }^{6}$ Differently from most recent analyses, this work focuses neither on the recent rise of populist and anti-establishment movements, nor on the electoral success of far-right parties, nor on the rising political polarization. Rather, it addresses the electoral outcomes as measured in terms of parties' political positions based on the University of North Carolina's Chapel Hill Expert Survey, as recently done also by Hooghe and Marks (2018). ${ }^{7}$ Moreover, in the attempt to carefully explore the relative roles of alternative facets of globalization, this work looks at the effects of globalization considering both import competition from China and immigration together rather than focusing on only one factor. The choice of the period under investigation

\footnotetext{
${ }^{6}$ Other recent papers have focused on the role of the Euro-area economic and financial crises, which we do not address in this work given the period of analysis. See, among others, Hernandez and Kriesi (2016) and Nicoli (2017).

${ }^{7}$ It could be argued that parties' orientations are endogenous with respect to the general sentiment of the population and that one could have a gradual shift of all parties toward one of the political dimensions considered in the analysis. This is the reason why the analysis is mainly based on exploiting the cross-regional variation (where local labour markets are used to determine regions): irrespective of the general political trends at the national level, the common working hypothesis is that conservative and nationalist parties might gain voting shares in the areas more exposed to globalization.
} 
and the inclusion of both immigration and import competition from China are motivated by the attempt to tackle the gradual shift in voting patterns in Italy rather than the very recent increase in anti-establishment movements. This latter has, allegedly, more to do with the effects of the European debt crisis and with political discontent with the ruling elites than with the long-lasting and cumulating effects exercised by globalization. Finally, the adoption of diversified units of analysis (thereby exploring various levels of disaggregation) and alternative sets of controls provides indirect evidence with regard to the existence of multiple channels, other than those associated with labor markets, through which globalization has affected local electoral outcomes in Italy. It is worth pointing out that the use of two alternative models (i.e., a mixed first-difference model and a fixed effects model), coupled with the use of different levels of aggregation, makes the findings of this study more robust than those of papers focusing on only one model and one level of aggregation. ${ }^{8}$

The paper is also related to an earlier wave of literature that studied from a microeconomic perspective the linkages between individual preferences, trade openness (Blonigen and McGrew, 2014; Mayda and Rodrik, 2005; Scheve and Slaughter, 2001b) and international migration (Mayda, 2006; Scheve and Slaughter, 2001a). Finally, the political science literature on populism and anti-establishment voting (Arzheimer, 2012; Barr, 2009; Caiani and Graziano, 2016; Hernandez and Kriesi, 2016; Kriesi, 2014; Mudde and Rovira Kaltwasser, 2018; Schedler, 1996; Schumacher and van Kersbergen, 2016), and particularly those papers investigating the economic determinants of the rise of the current wave of populism in Western liberal democracies (Guiso et al., 2017; Inglehart and Norris, 2016), have been another important reference. This said, this work does not include an analysis of individual-level vote choices/preferences (as done instead by Colantone and Stanig, 2018b) nor an analysis of the perceptions of the risks associated with globalization

\footnotetext{
${ }^{8}$ Although the motivations for adopting two alternative empirical models are diverse and will be discussed in detail in the methodological sections, it suffices to notice here that the mixed first-difference model is commonly used in the empirical works focusing on the impact of import competition on voting (see, for instance, Autor et al., 2016; Malgouyres, 2017), whereas the fixed effects model was used by Barone et al. (2016) in a recent study on the impact of immigration on the share of votes for the right-wing coalition in Italy.
} 
(as in Stockemer, 2015), which are left for further research.

The remainder of the paper is organized as follows. Section 2 provides an overview of political developments in Italy during the period of analysis and briefly describes the dynamics of inward migration and Chinese import competition. Section 3 describes the empirical strategy while Section 4 presents and discusses the results, exploring also the role of labour market controls and alternative units of analysis. Section 5 concludes.

\section{The Italian context: politics, immigration and international trade}

The institutional framework which characterized Italian politics during the period under scrutiny, the so-called 'Second Republic' (Seconda Repubblica), originates from a combination of domestic and international political events that, at the beginning of the nineties, led to a substantial discontinuity in the political landscape of the country. On the one hand, after the fall of the Berlin Wall, the Italian Communist Party, which used to be the most successful communist party in the Western Bloc, dissolved into a newly-formed and social democratic party, namely the Democratic Party of the Left. ${ }^{9}$ On the other hand, the so-called 'Bribesville' (Tangentopoli) scandal (with many local and national politicians involved in cases of actual and alleged corruption) led to the collapse of the Christian Democracy and of the Italian Socialist Party, the first and the third largest parties. The political void that followed was partly filled, in the 1994 elections, by Silvio Berlusconi's Forward Italy and by Umberto Bossi's Northern League, two parties that became pivotal political subjects of Italian politics during the following twenty years (Fella and Ruzza, 2013).

Even though the Second Republic marked a shift towards a quasi-majoritarian institutional arrangement, the Italian party system remained highly fragmented. In particular, the electoral laws favored the emergence of a two-coalition system, with coalitions consist-

\footnotetext{
${ }^{9}$ The Italian Communist Party was the second largest party at every general election during the period 1953-1987, always collecting at least $20 \%$ of the votes.
} 
ing in heterogeneous pools of political parties differentiating themselves from each other by adopting diverse positions on topical issues, such as immigration, economic openness, taxation and public spending. For example, centrist Christian democrats coexisted with libertarians and far-left parties in left-wing coalitions, whereas right-wing coalitions combined Christian democrats, separatists, nationalists and far-right parties. Political parties' attempts at differentiating themselves from others within the same coalition was conducive to a political environment characterized by a high party turnover, such that, on average, at every round of elections about 40 percent of the votes went to newly-formed parties. ${ }^{10}$ As we shall explain in what follows, our investigation purposefully exploits the highly variegated political system in Italy and, by focusing on groups of parties sharing similar political orientations rather than highly heterogeneous coalitions, it explores empirically the directions in which the electorate has moved in response to the increasing exposure to globalization. We maintain that studying the evolution of the votes obtained by the coalitions would not provide a clear picture of the way the electorate moved over time due to globalization-related shocks.

In the same period, the world economy became increasingly more integrated and Italy started facing the challenges posed by globalization. In a context in which international migration was on the rise, the number of foreign-born citizens residing in Italy increased by more than eleven times in twenty years (see Figure 1), from about 350 thousand in 1991 (0.6 per-cent of total population) to about four million in 2011 (6.8 per-cent of total population). Compared to other large European countries, in Italy immigration became a relevant phenomenon only in relatively recent times. For instance, in 1995, the percentage of immigrants was already above $10 \%$ in countries like Germany and France, while it was above $7 \%$ in the United Kingdom.

On the trade side, international agreements led to greater integration of low-wage countries into the world economy, thereby increasing the degree of international competition, especially for firms located in advanced countries and specialised in traditional

\footnotetext{
${ }^{10}$ Over the period 1994-2013, the Northern League was the only electorally relevant party that maintained its original name and symbol.
} 
Figure 1: Immigration dynamics in Italy (1994-2008)

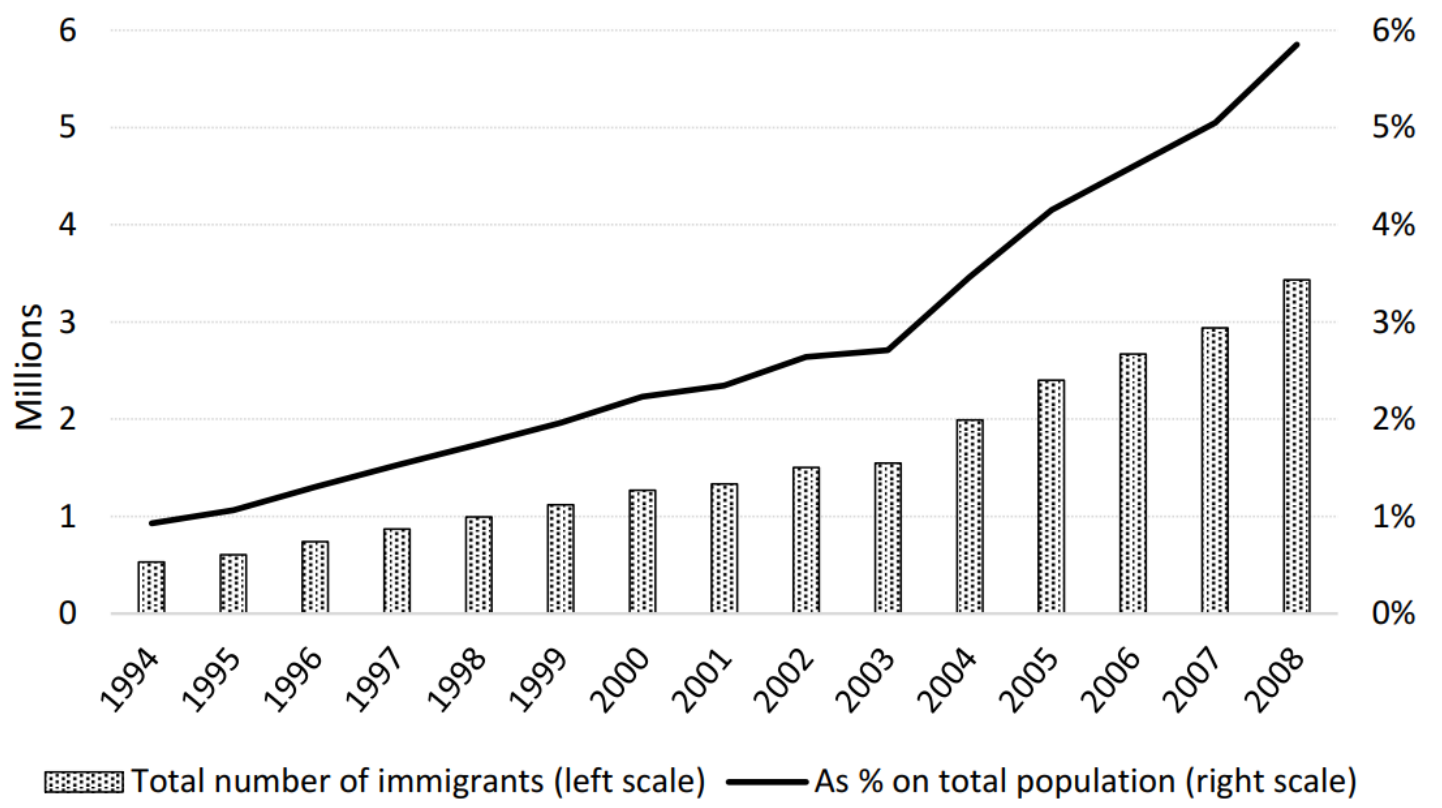

Source: Own elaborations based on data from Istat.

manufacturing in which low-wage countries had a comparative advantage. Given their traditional specialization in low-skilled and labor-intensive productions (e.g., the manufacturing of garments and leather products), several Italian manufacturing firms faced severe international competition that produced a negative and sizable effect on local employment, production and wage bills (Amighini et al., 2011; Federico, 2014). In this regard, the pattern of bilateral trade flows with China is emblematic of the difficulties faced by some Italian manufacturing sectors and those industrial districts specialised in the production of goods more directly competing with cheaper Chinese varieties. Indeed, between 1994 and 2008, Chinese imports registered a ninefold real increase (see Figure 2) and the bilateral trade surplus observed during the first half of the 1990s rapidly turned into a large bilateral deficit. ${ }^{11}$

This concise account of the progressively growing exposure of Italy to the most recent phase of globalization suffices to justify the intuition that the very same forces at work in

\footnotetext{
${ }^{11}$ Imports from China registered a very similar path in France, both in terms of their relative weight on total imports and and in terms of the dynamics of bilateral trade deficits. On the other hand, Chinese products accounted for more than $12 \%$ of total German imports in 2008, but Germany registered a bilateral trade surplus during most of the 2000s.
} 
Figure 2: Imports from China (1994-2008)

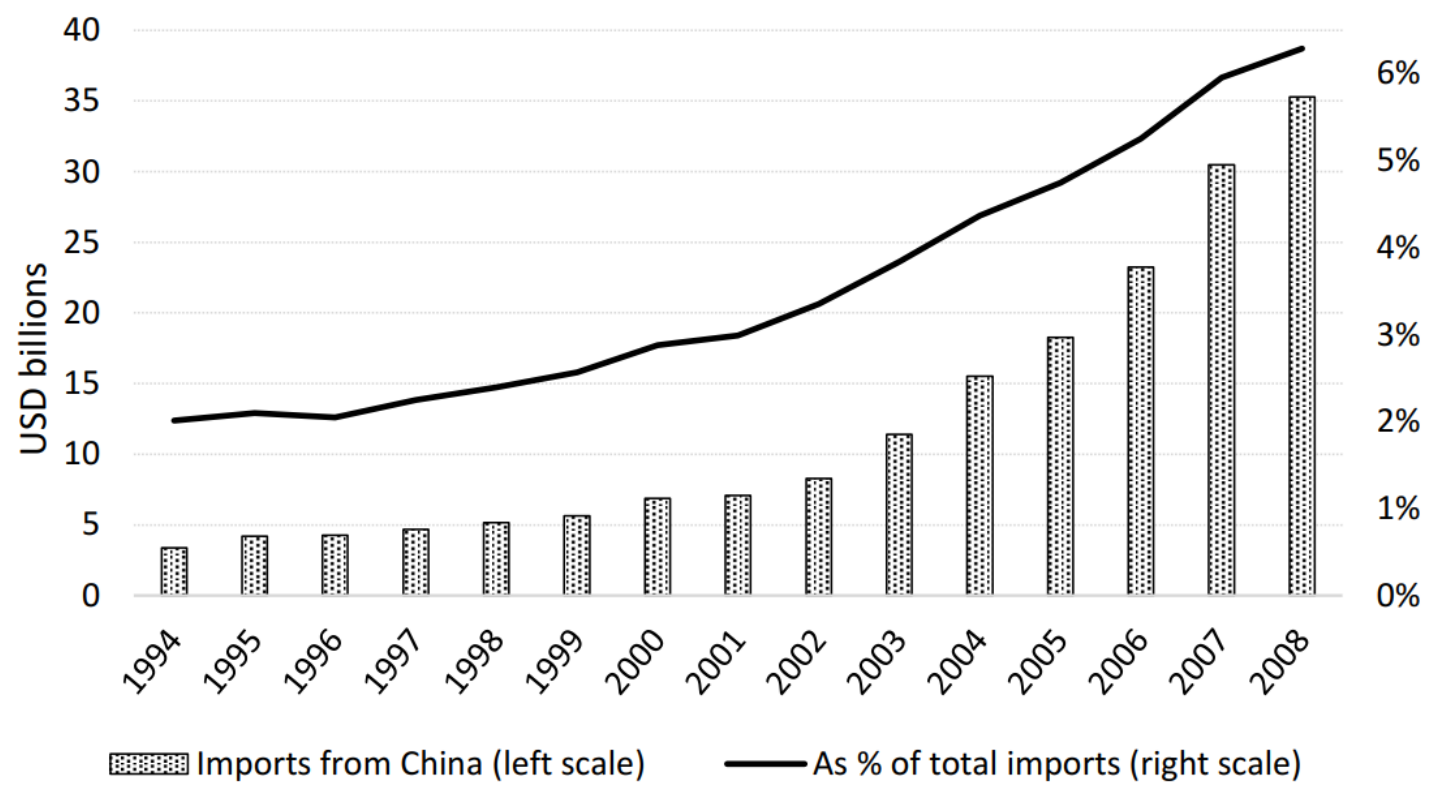

Source: Own elaborations based on data from UN Comtrade.

the elections in the US (Autor et al., 2016) and in other European countries (Colantone and Stanig, 2018a; Dippel et al., 2017; Halla et al., 2017; Malgouyres, 2017) might have had an impact also in the electoral outcomes of the general elections in Italy. The extraordinary heterogeneity of social and economic conditions across the various regions in Italy, mapped not only into the well-known North-South divide but also in a large number of highly specialized industrial districts and clusters, offers the opportunity to exploit the rich regional variation for the empirical identification of whether conservative and nationalist (liberal and globalist) parties gained (lost) voting shares in the areas more exposed to globalization. More precisely, the analysis will exploit the change in the exposure of local labor market areas (as well as municipalities and provinces) to immigration and import competition from China to assess their impact on the directions in which the Italian electorate moved during the period 1994-2008. 


\section{Empirical strategy}

\subsection{Data}

The empirical analysis is based on a panel data set of Italian municipalities, which has been constructed combining data from multiple sources and includes information on the economic structure, the demographic composition and the electoral outcomes of about 8,000 municipalities. The electoral outcomes refer to the municipality-level results at the Italian parliamentary elections held in 1994, 2001, 2006 and $2008 .^{12}$

Data on municipalities have then been aggregated at the level of local labor markets, which we adopt as the main geographical unit of analysis. However, we also repeat the analysis using more disaggregated units (municipalities) as well as more aggregated units (provinces). The borders of the local labor markets follow those traced by the Italian Institute of Statistics (Istat) for the Labor Market Areas (LMAs), that are subregional geographical units identified on the basis of daily commuting patterns. LMAs are functional geographic areas that go beyond administrative boundaries and represent economically integrated spatial units where residents can easily commute to work without changing place of residence. This makes LMAs suitable analytical units to study how voting behaviour is affected by globalization: most of the residents who vote in the municipalities included in a LMA also work (or have knowledge of/bonds of affection with workers located) in the same LMA and are thus similarly exposed to local changes in immigration and import competition.

Local labor markets evolve over time and, consistently with a process of increasing integration of the Italian economy, the number of LMAs identified by ISTAT declined from 781 in 1991 to 684 in 2001. ${ }^{13}$ To preserve internal consistency, in all our estimations

\footnotetext{
${ }^{12}$ Italy is a parliamentary Republic where, at every elections, all the voters can elect the members of the Chamber of Deputies while the voters aged 25 or older can vote also for the Senate. The two chambers share almost the same powers but the rules to assign the seats are different. In our study we only employ the votes for the Chamber of Deputies from the proportional part of the electoral system, thus avoiding issues related to changes in the electoral system that occurred between the 2001 and 2006 elections. Nevertheless, these changes in the electoral system are taken into account in the econometric analysis by the inclusion of year fixed effects.

${ }^{13}$ These figures exclude Valle d'Aosta.
} 
we employ the 1991 LMAs for the mixed first-difference model and the 2001 LMAs for the fixed effects model. Changing the classification of LMAs in the mixed first-difference model would have introduced confounding factors and jeopardized the very idea of pooling the changes occurred between 1994 and 2001, and those occurred between 2001 and 2008 . Conversely, the results based on the fixed effects model are robust to the use of the 1991 classification of LMAs. ${ }^{14}$ In the following analysis, we use the 2001 LMA classification to follow the approach adopted in Barone et al. (2016), therefore facilitating comparability.

Data on the local economic structure come from the 1991 and 2001 waves of the Census of Industry and Services (CIS) carried out by Istat. Containing detailed information on employment at the municipality level, the CIS makes it possible to break down the local industry mix at the three-digit level of the NACE industry classification. Data on the socio-demographic structure of municipalities and on regional series have also been taken from Istat databases. In particular, data on immigration, resident population, educational attainments and labor market variables (except value added per worker) come from the 1991 (for year 1994) and 2001 waves of the Population Census (CPOP). For years 2006 and 2008, we use data from the 'Demography in figures' database for resident population, while we linearly interpolate figures from the 2001 and 2011 census waves for educational attainments. Data on local levels of employment and participation rates for years 2006 and 2008 have been estimated using province-level values weighted by 2001 municipalitylevel census data. Data on sectoral value added, used to construct a measure of local real value added per worker, come from the OECD Structural Analysis Database (STAN). Specifically, we interact local employment structure, taken from the CIS, with the STAN two-digit sectoral value added. Regional data have been taken from the 'Territorial indicators for development policies' database.

Data on imports, disaggregated at the six-digit product level of the WCO Harmonized System (HS), have been drawn from the United Nations International Trade Statistics Database (Comtrade). Six-digit HS products have been matched with three-digit NACE

\footnotetext{
${ }^{14}$ Additional results are available upon request.
} 
sectors on the basis of Eurostat RAMON correspondence tables so as to relate trade flows and local industrial production.

Data on electoral outcomes by municipality were kindly provided by the Italian Interior Ministry. Party positioning in terms of the political dimensions explored in this work (more on this in Section 3.3) was taken from University of North Carolina's Chapel Hill Expert Survey 2014 (CHES), a dataset collecting experts' opinions on the stance that individual parties take over several political issues.

The mean values and the standard deviations of the variables, both for the model in first differences and for that in levels with fixed effects, calculated using the LMAs as unit of analysis, are presented in Table 1.

\subsection{Import competition from China and local presence of immigrants}

The intensity of local exposure to import competition from China, our first explanatory variable associated with exposure to globalization, has been measured by interacting local data on sectoral employment with country-level data on imported goods, both at the three-digit level of the NACE sectoral classification. This approach, based on the methodology pioneered by Autor et al. (2013), exploits regional heterogeneity in the industry mix to derive from national trade data a local measure of imports per worker, which is used as a proxy for the exposure to import competition at the local level. In other words, the local employment mix is used to create weights to allocate country-level imports to each local labor market. In this way, those LMAs that are specialized in the sectors characterized by high national import flows from China also exhibit a high value of imports per worker and a high degree of import competition. Formally, for the mixed first-difference model, we follow Autor et al. (2013) and define changes over time in Chinese imports per worker as

$$
\Delta I P W_{i t}^{c h n}=\frac{1}{L_{i, t-7}} \sum_{s} \eta_{i s, t-7} \Delta I M P_{s t}^{c h n}
$$


Table 1: Descriptive statistics - LMA level

\begin{tabular}{|c|c|c|c|c|c|}
\hline & \multicolumn{2}{|c|}{ Differences } & \multicolumn{3}{|c|}{ Levels } \\
\hline & 1994-2001 & 2001-2008 & 2001 & 2006 & 2008 \\
\hline Number of residents & $\begin{array}{c}72,551 \\
(208,849)\end{array}$ & $\begin{array}{c}72,794 \\
(204,887)\end{array}$ & $\begin{array}{c}83,117 \\
(222,252)\end{array}$ & $\begin{array}{c}85,713 \\
(229,741)\end{array}$ & $\begin{array}{c}86,979 \\
(235,673)\end{array}$ \\
\hline Share of over 65 in adult population & $\begin{array}{c}0.224 \\
(0.044)\end{array}$ & $\begin{array}{c}0.255 \\
(0.045)\end{array}$ & $\begin{array}{c}0.254 \\
(0.044)\end{array}$ & $\begin{array}{c}0.263 \\
(0.042)\end{array}$ & $\begin{array}{c}0.265 \\
(0.040)\end{array}$ \\
\hline Share of res w primary/lower sec edu & $\begin{array}{c}0.664 \\
(0.045)\end{array}$ & $\begin{array}{c}0.578 \\
(0.050)\end{array}$ & $\begin{array}{c}0.578 \\
(0.049)\end{array}$ & $\begin{array}{c}0.537 \\
(0.051)\end{array}$ & $\begin{array}{c}0.520 \\
(0.052)\end{array}$ \\
\hline Share of res w tertiary edu & $\begin{array}{c}0.023 \\
(0.011)\end{array}$ & $\begin{array}{c}0.051 \\
(0.017)\end{array}$ & $\begin{array}{c}0.052 \\
(0.017)\end{array}$ & $\begin{array}{c}0.067 \\
(0.020)\end{array}$ & $\begin{array}{c}0.072 \\
(0.021)\end{array}$ \\
\hline Unemployment rate & $\begin{array}{c}0.199 \\
(0.126)\end{array}$ & $\begin{array}{c}0.087 \\
(0.054)\end{array}$ & $\begin{array}{c}0.089 \\
(0.054)\end{array}$ & $\begin{array}{c}0.080 \\
(0.047)\end{array}$ & $\begin{array}{c}0.081 \\
(0.047)\end{array}$ \\
\hline Labor force participation rate & $\begin{array}{c}0.408 \\
(0.036)\end{array}$ & $\begin{array}{c}0.399 \\
(0.048)\end{array}$ & $\begin{array}{c}0.399 \\
(0.046)\end{array}$ & $\begin{array}{c}0.400 \\
(0.053)\end{array}$ & $\begin{array}{c}0.392 \\
(0.076)\end{array}$ \\
\hline Value added per worker & $\begin{array}{c}80.647 \\
(10.588)\end{array}$ & $\begin{array}{c}94.887 \\
(21.733)\end{array}$ & $\begin{array}{c}95.287 \\
(21.702)\end{array}$ & $\begin{array}{c}93.069 \\
(22.923)\end{array}$ & $\begin{array}{c}90.268 \\
(22.303)\end{array}$ \\
\hline Chinese imports per worker & $\begin{array}{c}0.153 \\
(0.187)\end{array}$ & $\begin{array}{c}1.180 \\
(1.115)\end{array}$ & $\begin{array}{c}0.389 \\
(0.459)\end{array}$ & $\begin{array}{c}1.097 \\
(1.133)\end{array}$ & $\begin{array}{c}1.554 \\
(1.516)\end{array}$ \\
\hline Share of immigrants x 100 & $\begin{array}{c}1.503 \\
(1.368)\end{array}$ & $\begin{array}{c}3.057 \\
(2.283)\end{array}$ & $\begin{array}{c}1.911 \\
(1.497)\end{array}$ & $\begin{array}{c}3.602 \\
(2.780)\end{array}$ & $\begin{array}{c}4.650 \\
(3.289)\end{array}$ \\
\hline Share of votes for far right $\mathrm{x} 100$ & $\begin{array}{c}-4.367 \\
(5.256)\end{array}$ & $\begin{array}{l}-5.439 \\
(8.777)\end{array}$ & $\begin{array}{c}15.219 \\
(5.650)\end{array}$ & $\begin{array}{c}17.260 \\
(5.885)\end{array}$ & $\begin{array}{c}9.490 \\
(10.755)\end{array}$ \\
\hline Share of votes for far left $\mathrm{x} 100$ & $\begin{array}{c}0.486 \\
(2.309)\end{array}$ & $\begin{array}{l}-2.439 \\
(1.982)\end{array}$ & $\begin{array}{c}6.430 \\
(2.735)\end{array}$ & $\begin{array}{c}9.416 \\
(3.176)\end{array}$ & $\begin{array}{c}4.025 \\
(1.414)\end{array}$ \\
\hline Share of votes for right wing $\mathrm{x} 100$ & $\begin{array}{l}12.167 \\
(9.127)\end{array}$ & $\begin{array}{c}3.502 \\
(4.330)\end{array}$ & $\begin{array}{c}53.438 \\
(10.699)\end{array}$ & $\begin{array}{c}49.591 \\
(11.169)\end{array}$ & $\begin{array}{c}56.691 \\
(10.503)\end{array}$ \\
\hline Share of votes for TAN x 100 & $\begin{array}{l}-2.958 \\
(7.693)\end{array}$ & $\begin{array}{l}-0.467 \\
(4.480)\end{array}$ & $\begin{array}{c}57.391 \\
(10.797)\end{array}$ & $\begin{array}{c}54.718 \\
(11.128)\end{array}$ & $\begin{array}{c}56.691 \\
(10.503)\end{array}$ \\
\hline Voters' turnout x 100 & $\begin{array}{l}-4.372 \\
(3.705)\end{array}$ & $\begin{array}{c}1.982 \\
(7.184)\end{array}$ & $\begin{array}{l}78.048 \\
(8.920)\end{array}$ & $\begin{array}{l}82.442 \\
(5.562)\end{array}$ & $\begin{array}{l}79.669 \\
(5.675)\end{array}$ \\
\hline Observations & 781 & 781 & 684 & 684 & 684 \\
\hline
\end{tabular}

Notes: The table reports the mean value and, in parentheses, the standard deviation. The analytical units are: 1991 LMAs for the mixed first-difference model (Differences) focusing on changes during the periods 1994-2001 and 2001-2008; 2001 LMAs for the fixed effects model (Levels) focusing on the years 2001, 2006 and 2008. The values reported for the model in differences are at the beginning of the period for number of residents, share of over 65 in adult population, share of residents with primary or lower secondary education, share of residents with tertiary education, unemployment rate, labor force participation rate and value added per worker, and in differences for all other variables. Value added per worker is expressed in thousands of constant 2009 Euros. Chinese imports per worker is expressed in thousands of constant 2010 US dollars. The variables for the shares of votes represent in order the share of votes for far-right parties, far-left parties, right-wing parties and traditional/authoritarian/nationalist parties.

where $\Delta I M P_{s t}^{c h n}=I M P_{s t}^{c h n}-I M P_{s, t-7}^{c h n}, I M P_{s t}^{c h n}$ indicates the value (expressed in thousands of constant 2010 US dollars) of imports from China of goods belonging to the three-digit NACE sector $s$ at time $t, L_{i, t-7}$ is the total employment of local labor market $i$ at the beginning of the period, and $\eta_{i s, t-7}=L_{i s, t-7} / L_{s, t-7}$ stands for the fixed weight 
of local labor market $i$ in country-level employment for sector $s$ at the beginning of the period. Initial-period values for the employment structure ensure that local specialization is not due to contemporaneous trade exposure. The diversity in employment structures in manufacturing across LMAs at the beginning of the period creates enough regional variation in local exposure to import competition to identify the parameter of the variable of interest. Instead, for the fixed effects model, we use the level of Chinese imports per worker of local labor market $i$ at time $t$, defined as

$$
I P W_{i t}^{c h n}=\frac{1}{L_{i t}} \sum_{s} \eta_{i s 0} I M P_{s t}^{c h n}
$$

where $\eta_{i s 0}=L_{i s 0} / L_{s 0}$ stands for the fixed weight of local labor market $i$ in country-level employment for sector $s$ in 2001 (at the beginning of the period, $t=0$ ). ${ }^{15}$

Our second explanatory variable associated with exposure to globalization is the intensity of the local presence of immigrants. For the mixed first-difference model, this is captured by changes in immigrants per resident in LMA $i$ at period $t$ times 100, that is $\Delta I M M_{i t}^{\text {shr }}=100 \times \Delta$ Immigrants $_{i t} /$ Residents $_{i, t-7}$, where $\Delta$ Immigrants $_{i t}=$ Immigrants $_{i t}-$ Immigrants $_{i, t-7}$. For the fixed effects model, we use the share of foreign citizens residing in LMA $i$ at period $t$ times 100 , that is $I M M_{i t}^{s h r}=100 \times$ Immigrants $_{i t} /$ Residents $_{i t}$. The measurement of the local presence of immigrants is based on census data and on intercensal population estimates that, compared to survey data, are less subject to measurement error, a relevant issue when it comes to measuring immigration. ${ }^{16}$ However, besides the accuracy of census data, the risk of measurement error is also minimized by the aggregation of municipalities into LMAs.

\footnotetext{
${ }^{15}$ The fixed effects estimates are also robust to the use of employment weights based on data for 1991.

${ }^{16}$ Since the exact number of foreign citizens is not available for year 1994, for that year we use the number of immigrants and the number of residents in 1991.
} 


\subsection{Classification of electoral outcomes}

The identification of the impact of globalization on local electoral outcomes requires a definition of both the political dimensions used to analyze political parties and the criteria adopted to classify them. In this section, we present the methodology employed to this end and the main decisions taken.

Three factors contribute to make it difficult to classify Italian political parties: their variety, their high turnover rate and their frequent repositioning. Notwithstanding the difficulty to position each party on the continuous axis of the political spectrum referring to each of the relevant political dimensions necessary to identify political agendas and identities, the categorization of parties according to dichotomous scales appears less controversial. For instance, parties like the Northern League and National Alliance can convincingly be considered as far-right parties with traditionalist and authoritarian tendencies, whereas the Communist Refoundation Party can be certainly considered as belonging to the far-left.

The average number of political parties participating at every election is large, as is the dispersion of votes. Therefore, we include all parties that (i) gained at least one seat in the Chamber of Deputies, (ii) got at least one percent of votes at the national level or (iii) got at least ten percent of votes in a single LMA. As a result, even though few small parties have been excluded, our analysis covers about $99 \%$ of the votes cast.

Our analysis is based on a classification of Italian political parties that relies on CHES scores. The CHES 2014 provides scores on a scale from 0 to 10 for the political stances of most of the parties that have run for general elections in 28 European countries from 1996 to 2014. Two important advantages of CHES scores are that (a) they capture the position of parties on different political issues and (b) they change over time, keeping track, at every round of elections, of party repositioning. In particular, we employ the scores on parties' positions on the left versus right (L-R) and on the green/alternative/libertarian versus traditional/authoritarian/nationalist (GAL-TAN) dimensions in order to classify Italian political parties into four groups: far-right parties, far-left parties, right-wing 
parties and TAN parties. ${ }^{17}$ A high position of the L-R score indicates a party right-wing positioning, thus we include in the group of far-right parties every party with a L-R score greater than or equal to $7 .{ }^{18}$ Similarly, we consider as right-wing all the parties with a L-R score greater than 5 and as far-left those with a L-R score lower than 3 . In an analogous manner, TAN parties are defined as those parties with a GAL-TAN score greater than 5. After having classified each party in each group, we calculate the percentage of votes obtained by each group of parties at the elections for the Chamber of Deputies from the proportional part of the electoral system.

Even though the analysis does not explicitly study the effects of globalization on the electoral performances of center-left and green/alternative/libertarian (GAL) parties, they can however be easily derived from the regressions on right-wing and TAN parties respectively. Indeed, except for minor (and not relevant) discrepancies due to a few small parties that we have not been able to categorize, the shares of votes for center-left and GAL parties are the complement of those for right-wing and TAN parties. It follows that, for instance, a positive and significant effect of immigration on the percentage of votes for TAN parties implies a negative and equally significant effect of immigration on the percentage of votes for GAL parities.

It is worth noting that the absence of a two-party political system in Italy brings certain advantages for the empirical analysis. The relatively high variety of political parties provides the opportunity to map them into different but partially overlapping groups according to their positions on distinct political dimensions. This is an important aspect that, together with the regional differentiation in terms of the sectoral employment

\footnotetext{
${ }^{17}$ The GAL-TAN dimension of party positioning is complementary to the usual left-right cleavage and it indicates parties' stance on issues such as freedom ad rights. While GAL parties support expanded personal and civil rights, TAN parties 'value order, tradition and stability and believe that the government should be a firm moral authority on social and cultural issues' (Bakker et al., 2015). While the L-R and GAL-TAN categories often go hand in hand, there are some notable exceptions. For example, while the 'Italy of Values' party and the regional 'South Tyrolean People's Party' are in some years categorized as left, they are always categorized as traditional/authoritarian/nationalist. On the other hand, in 2006 the short-lived 'Christian-Democrat-New Socialist Party' was categorized as right and green/alternative/libertarian.

${ }^{18}$ The only exception to this categorization is for the positioning of Silvio Berlusconi's 'Forward Italy' and 'People of Freedom' parties in 2006 and 2008 respectively, whose scores were slightly above the threshold and so they would have been included incorrectly among far-right parties.
} 
structure, creates enough variation to identify the coefficients of interest.

Finally, two methodological qualifications are in order. First, even though CHES takes into account all the most important parties, it does not capture a number of small parties, not representative at the national level. These unclassified local parties, in fact, may be relevant for our analysis and this forces us to impute L-R and GAL-TAN scores for them. Fortunately, since most of such unclassified parties are either on the far-left or on the far-right, the imputation does not represent a major concern. Second, as CHES starts only in 1996, we are forced to impute the values for the parties participating in the 1994 elections. Also in this case, the imputation does not seem too controversial: first, the political positions of the parties participating in the elections of both 1994 and 1996 can be derived from the CHES classification for 1996 given that it is unlikely that they changed significantly over two years; second, the CHES database does in fact include the evaluation of the two parties that participated only in the 1994 elections.

\subsection{Econometric models}

We analyze the impact of globalization on local electoral outcomes in Italy by means of two different econometric models, both dealing with unobserved time-invariant heterogeneity. In the first place, we estimate a mixed first-difference model covering two seven-year periods, 1994-2001 and 2001-2008 (stacked first differences). This is the most commonly used model in the literature focusing on the impact of local exposure to import competition on electoral outcomes (Autor et al., 2016). ${ }^{19}$ The time periods have been chosen to ensure consistency in the time length separating different general elections and, thus we include the elections that took place in 1994, 2001 and 2008 and exclude those in 1996 and 2006. Secondly, we run a fixed effects model for the elections in 2001, 2006 and 2008, as done by Barone et al. (2016). We exclude from this analysis the general elections of 1994 and 1996 to ensure the availability of data for all time-varying variables,

\footnotetext{
${ }^{19}$ While electoral results may evolve quite rapidly, the composition of import flows and the sectoral structure of local employment do not vary too fast. This explains the adoption of relatively long time spans, following the approach suggested by Autor et al. $(2016,1)$.
} 
in particular the instruments described in Section 3.5. ${ }^{20}$

The baseline specification of the mixed first-difference model is

$$
\Delta y_{i t}=\alpha_{1} \Delta I P W_{i t}^{c h n}+\alpha_{2} \Delta I M M_{i t}^{s h r}+\boldsymbol{x}_{i, t-7}^{\prime} \boldsymbol{\gamma}+\boldsymbol{r}_{i t}^{\prime} \boldsymbol{\psi}+\boldsymbol{\tau}_{t}^{\prime} \boldsymbol{\delta}+\boldsymbol{\zeta}_{i}^{\prime} \boldsymbol{\kappa}+\epsilon_{i t}
$$

where $\Delta y_{i t}=y_{i t}-y_{i, t-7}$ denotes the change in the share of votes of a certain group of parties or the change in voters' turnout in LMA $i$ between $t$ and $t-7$. In addition, $\boldsymbol{x}_{i, t-7}$ is a vector of controls at the LMA level measured at the beginning of the period, $\boldsymbol{r}_{i t}$ is a vector of controls at the regional level measured at the end of the period due to lack of data for year $1994,{ }^{21} \tau_{t}$ represents a vector of time fixed effects and $\zeta_{i}$ is a vector of fixed effects at the regional (NUTS 2) level to control for time-invariant unobserved factors at a higher level of geographical aggregation. ${ }^{22}$

The LMA-level controls include the number of residents, the share of residents over 65 in the adult population, the share of residents with primary or lower secondary education, the share of residents with tertiary education, the unemployment rate, the labor force participation rate and the value added per worker. The regional-level controls include the share of informal labor, the share of expenditure on cultural activities, tickets in cultural activities per capita, volunteering, attractiveness of universities, internet diffusion and hospital migration rate (to other regions). Although the role of each of these controls might be of interest per se, their inclusion in the specification serves only to control for relevant time-varying omitted variables. This makes the estimations less likely to suffer omitted variable bias and allows one to estimate the direct impact of the variables of interest once possible indirect effects are controlled for.

\footnotetext{
${ }^{20}$ We exclude the 2013 elections because, as argued in the Introduction, we believe that the scenario that followed the double-dip recession of the Eurozone introduced new factors that require a distinct analysis. Moreover, the exclusion of 2013 makes it possible to preserve comparability with Barone et al. (2016) and across our two empirical models.

${ }^{21}$ All results are robust to the exclusion of the regional-level controls.

${ }^{22}$ If a LMA overlaps two or more regions, it is assigned to the region where the higher proportion of its residents live.
} 
The baseline specification of the fixed effects model is

$$
y_{i t}=\beta_{1} I P W_{i t}^{c h n}+\beta_{2} I M M_{i t}^{s h r}+\boldsymbol{x}_{i t}^{\prime} \boldsymbol{\lambda}+\boldsymbol{r}_{i t}^{\prime} \boldsymbol{\chi}+\boldsymbol{\tau}_{t}^{\prime} \boldsymbol{\nu}+\boldsymbol{\phi}_{i}^{\prime} \boldsymbol{\theta}+v_{i t},
$$

where all the variables are in levels, all the socio-economic and demographic controls in vectors $\boldsymbol{x}$ and $\boldsymbol{r}$ are contemporaneous and $\phi_{i}$ represents a vector of LMA fixed effects.

It is worth noticing that in our estimation the two models differ along several dimensions. First, they differ in terms of the way in which they control for unobserved time-invariant factors and the assumptions regarding the error term, in particular the presence of heteroskedasticity and serial correlation. Second, socio-economic and demographic controls enter in levels in both models with a different lag structure, thereby accounting for diverse aspects of time-varying factors. Third, they differ in the time span of the analyses (1994-2008 versus 2001-2008) and they focus on different electoral results $\left(1994,2001,2008\right.$ versus 2001, 2006, 2008). ${ }^{23}$ As different strands of the literature generally choose just one of these two models without providing unequivocal reasons, the adoption of both models ensures the comparability of our findings with those obtained by all previous works. Moreover, the use of both models makes it possible to explore the robustness of our main findings to alternative ways to deal with unobserved time-invariant heterogeneity, as incidentally suggested by Autor et al. (2013).

In Section 4.3, we shall present the results obtained by estimating these specifications without including the controls for the unemployment rate, the labor force participation rate and the value added per worker. These additional specifications are run to gain some insights about the mediating role played by local labor markets in the transmission of globalization shocks into electoral outcomes.

\footnotetext{
${ }^{23}$ As explained in Section 3.1, the models also differ due to the fact that the mixed first-difference model adopts the 1991 classification of LMAs, whereas the fixed effects model uses the 2001 classification of LMAs by Istat. This is, however, almost immaterial for the results.
} 


\subsection{Endogeneity issues and instrumental variable approach}

If the local presence of migrants and the local intensity of import competition from China were exogenous, the specifications in equations (3) and (4) would correctly identify their effects on local electoral outcomes. Difficulties arise, however, when both the dependent variable and the regressors are correlated with unobserved shocks. This could be the case, for example, if the increase in imports from China in a particular LMA is due to a boost in demand for the goods produced in the sector in which that LMA is specialized. The beneficial effects of the demand surge on local labor markets could affect electoral outcomes in a way that differs from the effect of a supply-driven increase in import exposure. Effects of this kind would clearly bias the estimates. Similarly, the electoral outcomes may be driven by unobserved improvements in the local economic environment that attract (or keep away) migrant workers, thereby biasing downward (upward) in absolute value the estimated coefficient. Moreover, as we shall discuss, if new immigrants locate closer to previous migrants coming from the same country of origin, there might be problems of reverse causality and self-selection. Under these circumstances, OLS estimations would suffer of endogeneity problems and could potentially be biased. Therefore, we rely on an instrumental variable (IV) approach and the two-stage least squares (2SLS) estimator.

Following the methodology developed by Autor et al. (2013), we address the potential endogeneity of imports per worker by using information on the imports from China recorded in eight high-income countries that do not belong to the European Union. ${ }^{24}$ In so doing, we exploit non-EU trade patterns to identify the exogenous and 'supply-driven' component of the rise in Chinese imports determined, for instance, by the lowering of multilateral trade barriers (as China was admitted to the World Trade Organization at the end of 2001) or by the increase in Chinese firms' productivity. Thus, this strategy assumes that product demand shocks are not correlated between Italy the chosen high-income countries and that the growth in imports from China is due to Chinese productivity

\footnotetext{
${ }^{24}$ These countries are Australia, Canada, Israel, Japan, Korea, New Zealand, Norway and USA. We choose non-EU countries because shocks within the EU are strongly correlated across countries.
} 
growth, rather than slow productivity growth in Italy, particularly in those sectors where China has a comparative advantage.

More precisely, in the mixed first-difference model, we instrument $\Delta I P W_{i t}^{c h n}$ with a new variable defined as

$$
\Delta \widetilde{I P W}_{i t}^{c h n}=\frac{1}{L_{i, t-7}} \sum_{s} \eta_{i s, t-7} \Delta \widetilde{I P W}_{s t}^{c h n}
$$

where $\Delta \widetilde{I P W}_{s t}^{c h n}=\widetilde{I M P}_{s t}^{c h n}-\widetilde{I M P}_{s, t-7}^{c h n}$ and $\widetilde{I M P}_{s t}^{c h n}$ represents the average of sectoral imports from China of the eight non-EU countries at time $t$ expressed in thousands of constant 2010 US dollars. ${ }^{25}$ Similarly, in the fixed effects model, the instrument for $I P W_{i t}^{c h n}$ is given by

$$
{\widetilde{I P W_{i t}}}^{c h n}=\frac{1}{L_{i t}} \sum_{s} \eta_{i s 0} \widetilde{I M P}_{s t}^{c h n}
$$

Immigration might also be endogenous. In this case, endogeneity may stem from two sources. First, some communities may increase their 'openness' toward foreign residents more than other communities and migrants may choose to settle down where the environment is less confrontational, thus creating a problem of reverse causality. Moreover, endogeneity problems may arise due to local demand shocks that simultaneously affect electoral outcomes and the inflow of foreign-born residents. We tackle these issues by using the idea that immigrants are likely to move to areas where other immigrants live. Thus, we instrument $\Delta I M M_{i t}^{s h r}$ in the mixed first-difference model with the share of immigrants at the beginning of each period, $I M M_{i, t-7}^{s h r}$, and by instrumenting $I M M_{i t}^{s h r}$ in the fixed effects model with its five-year lag, $I M M_{i, t-5}^{s h r} \cdot{ }^{26}$ This approach follows Otto

\footnotetext{
${ }^{25}$ Reverse causality issues should not be a source of concern. As local imports are unobservable, the initial period distribution of sectoral employment is used to build a proxy of local import competition that varies over time. Hence, to the extent that the initial period distribution of industries across and within local labor markets is independent from the future shifts of national import flows from China, reverse causality is ruled out by construction. Put it in other words, as the variable of interest is built by using a shift-share approach, the only possible endogeneity problem is due to omitted variables affecting the shifts in national import flows and local voting preferences.

${ }^{26}$ As mentioned previously, it is the very need to use a lagged value of immigration, combined with
} 
and Steinhardt (2014) and relies on the assumption that time lags are long enough to satisfy the exclusion restriction condition, and thus overcome the endogeneity issues, after conditioning on covariates while ensuring that the instrument is still informative. ${ }^{27}$

This strategy to identify the causal effect of immigration differs from the approach recently used by, among others, Barone et al. (2016) and Halla et al. (2017). These papers instrument the local intensity of immigration with the national-level stock of immigrants by nationality weighted by the historical share of immigrants from different countries at the local level. This shift-share approach, pioneered by Bartik (1991) and Card (2001), exploits the network effect in international migration (whereby the lagged geographical distribution of immigrants drives subsequent inflows) to calculate an exogenous 'supply-driven' measure of immigration at the local level. While this IV strategy has been successfully adopted in several studies looking at the effects of migration on local labor market dynamics, it might not be equally desirable when the dependent variable is electoral outcomes. If the relative importance of immigrants from different nationalities is the basis for allocating national immigration flows to local communities over time, the instrumented measure of immigration may fail to capture the impact of large increases of immigrants who do not belong to any embedded community, even though these phenomena are very important to explain changes in the attitude of locals towards immigrants. Moreover, as pointed out by Jaeger et al. (2018), shift-share past settlement instruments may not necessarily be bullet proof under all circumstances. ${ }^{28}$ Indeed, in our context, the

limited data availability for this variable, that forces us to consider only the elections from 2001 onwards for the fixed effects model. It should also be noted that using longer lags is not possible again due to limited data availability for immigration.

${ }^{27}$ Additional standard assumptions also need to apply, including random assignment of the instruments and monotonicity (Angrist and Krueger, 2001). All these assumptions make it possible to interpret our estimates as local average treatment effects. In particular, the coefficients on Chinese imports per worker estimate the weighted average effect of import competition on electoral outcomes, where higher weights are given to those areas that, because of their initial industrial specialization, became more exposed to the exogenous increase in Chinese competition that occurred in all countries. Similarly, the coefficients on immigrants per resident identify the weighted average effect of immigration on electoral outcomes, where higher weights are given to those areas that experienced greater immigration in previous periods.

${ }^{28}$ Shift-share past settlement instruments, for instance, risk conflating the short-term and long-term responses to immigration shocks if the spatial distribution of immigrant inflows is stable over time (see Jaeger et al., 2018, for details). According to Jaeger et al. (2018), moreover, results obtained using past settlement instruments can be little stable across different time periods. To see whether these are relevant issues, one would need to follow Jaeger et al. (2018)'s suggestion and use a multiple instrumentation 
shift-share instrument for immigration share is not informative, especially when data are more aggregated (at the level of local labor markets or provinces). Therefore, in what follows, we will focus on the instrumental variable approach used by Otto and Steinhardt (2014) and based on lagged values of immigration stocks. ${ }^{29}$

\section{Results and discussion}

\subsection{Baseline results}

The estimated coefficients of the baseline specifications (3) and (4), i.e., the mixed firstdifference model and the fixed effects model (that is a specification in levels with LMA fixed effects), are summarized in Table 2 and Table 3, respectively. These OLS estimates (augmented with fixed effects) assume that there are no endogeneity issues. All regressions are significant overall and the R-squared are generally high, with values ranging from 0.278 to 0.718 .

Despite the differences listed in the previous section, the two models return, in qualitative terms, largely similar results. In both models, the exposure to Chinese import competition turns out to be positively and significantly correlated with the share of votes for right-wing and far-right parties. Similarly, the presence of immigrants is positively associated with the electoral performance of right-wing and TAN parties, while it is negatively associated with the vote shares of far-left parties and with the overall turnout rate. This is in line with previous findings in the literature both for Italy (available for the case of migrants) and for other Western liberal countries.

However, the two models also show a few qualitative differences. While the fixed effects model yields a positive and significant relationship between the local presence of immigrants and the vote shares of far-right parties, the mixed first-difference model does not show such relationship (the estimated coefficient is negative, but not statistically

approach including further lags of the instrument. Unfortunately, we do not have enough time periods to employ further lags.

${ }^{29}$ Additional results based on the shift-share past settlement as the instrumental variable for the immigration share are available upon request. 
Table 2: First-difference model - Baseline results

\begin{tabular}{|c|c|c|c|c|c|}
\hline & $\begin{array}{c}(1) \\
\Delta \text { FarRight }\end{array}$ & $\begin{array}{c}(2) \\
\Delta \text { FarLeft }\end{array}$ & $\begin{array}{c}(3) \\
\Delta \text { Right-wing }\end{array}$ & $\begin{array}{c}(4) \\
\Delta T A N\end{array}$ & $\begin{array}{c}(5) \\
\Delta \text { Turnout }\end{array}$ \\
\hline$\Delta I P W^{C h n}$ & $\begin{array}{c}1.178^{* * *} \\
(0.234)\end{array}$ & $\begin{array}{c}0.126^{* *} \\
(0.056)\end{array}$ & $\begin{array}{c}0.686^{* * *} \\
(0.185)\end{array}$ & $\begin{array}{c}0.409^{* * *} \\
(0.158)\end{array}$ & $\begin{array}{c}-0.382^{*} \\
(0.196)\end{array}$ \\
\hline$\Delta I M M^{s h r}$ & $\begin{array}{c}0.029 \\
(0.112)\end{array}$ & $\begin{array}{c}-0.065^{* *} \\
(0.031)\end{array}$ & $\begin{array}{c}0.556^{* * * *} \\
(0.087)\end{array}$ & $\begin{array}{c}0.295^{* * *} \\
(0.072)\end{array}$ & $\begin{array}{c}-0.472^{* * *} \\
(0.088)\end{array}$ \\
\hline LMA controls & yes & yes & yes & yes & yes \\
\hline Regional (NUTS2) controls & yes & yes & yes & yes & yes \\
\hline Region (NUTS2) fixed effects & yes & yes & yes & yes & yes \\
\hline Year fixed effects & yes & yes & yes & yes & yes \\
\hline Observations & 1,562 & 1,562 & 1,562 & 1,562 & 1,562 \\
\hline R-squared & 0.442 & 0.581 & 0.618 & 0.422 & 0.443 \\
\hline
\end{tabular}

Notes: The dependent variable in columns (1) through (4) is the percentage point change in the votes for each group of parties (far right, far left, right-wing, traditional/authoritarian/nationalist) and in column (5) the percentage point change in voters' turnout. The LMA controls include number of residents, share of residents above 65 in the adult population, share of residents with primary or lower secondary education, share of residents with tertiary education, unemployment rate, labor force participation rate and value added per worker. The regional controls include hospital migration, informal labor, share of expenditure on cultural activities, tickets in cultural activities per capita, volunteering, attractiveness of universities and internet diffusion. Standard errors clustered at the LMA level are shown in parentheses. ${ }^{\star},{ }^{\star \star}$ and ${ }^{\star \star \star}$ indicate coefficients significantly different from zero at the $10 \%, 5 \%$ and $1 \%$ level respectively.

different from zero). This difference in results is most likely due to the bias associated with the potential endogeneity issues discussed in Section 3.5, which will be tackled in the next section. In addition, while the mixed first-difference regressions find positive and significant correlations between Chinese import competition and the electoral performance of far-left and TAN parties, such relationships are not significant in the fixed effects regressions.

Overall, both the mixed first-difference and the fixed effects estimates show significant correlations between our two proxies of local exposure to globalization and local electoral outcomes. Consistently with conventional wisdom, the results seem to suggest that globalization produces 'winners' and 'losers' and that political parties with a marked anti-globalization stance tend to be more successful where the effects of globalization are more pronounced. 
Table 3: Fixed effects model - Baseline results

\begin{tabular}{|c|c|c|c|c|c|}
\hline & $\begin{array}{c}(1) \\
\text { FarRight }\end{array}$ & $\begin{array}{c}(2) \\
\text { FarLeft }\end{array}$ & $\begin{array}{c}(3) \\
\text { Right-wing }\end{array}$ & $\begin{array}{c}(4) \\
T A N\end{array}$ & $\begin{array}{c}(5) \\
\text { Turnout }\end{array}$ \\
\hline$I P W^{C h n}$ & $\begin{array}{c}1.028^{* * *} \\
(0.304)\end{array}$ & $\begin{array}{l}-0.041 \\
(0.052)\end{array}$ & $\begin{array}{c}0.462^{* *} \\
(0.203)\end{array}$ & $\begin{array}{c}0.121 \\
(0.144)\end{array}$ & $\begin{array}{c}0.101 \\
(0.204)\end{array}$ \\
\hline$I M M^{s h r}$ & $\begin{array}{c}0.807^{* * *} \\
(0.198)\end{array}$ & $\begin{array}{c}-0.123^{* * *} \\
(0.044)\end{array}$ & $\begin{array}{c}1.383^{* * *} \\
(0.287)\end{array}$ & $\begin{array}{c}0.565^{* * *} \\
(0.115)\end{array}$ & $\begin{array}{c}-1.638^{* * *} \\
(0.186)\end{array}$ \\
\hline LMA controls & yes & yes & yes & yes & yes \\
\hline Regional (NUTS2) controls & yes & yes & yes & yes & yes \\
\hline LMA fixed effects & yes & yes & yes & yes & yes \\
\hline Year fixed effects & yes & yes & yes & yes & yes \\
\hline Observations & 2,052 & 2,052 & 2,052 & 2,052 & 2,052 \\
\hline R-squared & 0.595 & 0.718 & 0.330 & 0.278 & 0.442 \\
\hline
\end{tabular}

Notes: The dependent variable in columns (1) through (4) is the percentage of votes for each group of parties (far right, far left, right-wing, traditional/authoritarian/nationalist) and in column (5) the percentage value for voters' turnout. The LMA controls include number of residents, share of residents above 65 in the adult population, share of residents with primary or lower secondary education, share of residents with tertiary education, unemployment rate, labor force participation rate and value added per worker. The regional controls include hospital migration, informal labor, share of expenditure on cultural activities, tickets in cultural activities per capita, volunteering, attractiveness of universities and internet diffusion. Standard errors clustered at the LMA level are shown in parentheses. ${ }^{\star \star}$ and ${ }^{\star \star \star}$ indicate coefficients significantly different from zero at the $5 \%$ and $1 \%$ level respectively.

\subsection{IV results}

To tackle the possible endogeneity issues discussed in Section 3.5, the models are estimated via 2SLS, employing instruments for the variables proxying globalization. The first-stage results of the 2SLS regressions are reported in Table 4. The instruments used in the 2SLS regressions are informative and the estimates do not suffer problems related to weak instruments, as shown by the high values for the Kleibergen-Paap F statistics, larger than the Stock-Yogo critical value equal to 7.03, with the exception of the regressions at the province level. The first-stage regressions show that Chinese import competition has increased in analogous ways in Italy and in the eight non-EU countries used to construct the instrument. Similarly, lagged immigration is associated with larger changes as well as higher values of immigration in the future. ${ }^{30}$

\footnotetext{
${ }^{30}$ The reduced-form results are available in Appendix A. It is interesting to notice that the reducedform regressions produce estimates with signs and significance completely in line with the 2SLS estimates. This is a clear sign that the effects of interest are present and the instruments are not weak (Angrist and Krueger, 2001), even when more aggregated analytical units are used. Indeed, only for the province-level regressions, the Kleibergen-Paap F statistics is below the critical value, but the instruments still appear
} 
Table 4: First-stage regressions

\begin{tabular}{|c|c|c|c|}
\hline First-difference model & LMA & Municipality & Province \\
\hline \multicolumn{4}{|l|}{ Dependent variable: $\triangle I P W^{C h n}$} \\
\hline$\widetilde{\Delta P W}^{C h n}$ & $\begin{array}{c}0.2970^{* * *} \\
(0.0373)\end{array}$ & $\begin{array}{c}0.1799^{* * *} \\
(0.0404)\end{array}$ & $\begin{array}{l}0.2548^{*} \\
(0.1305)\end{array}$ \\
\hline$I M M^{s h r}, t-7$ & $\begin{array}{c}0.1129^{* * *} \\
(0.0265)\end{array}$ & $\begin{array}{c}0.0619^{* * *} \\
(0.0113)\end{array}$ & $\begin{array}{c}0.1826^{* * *} \\
(0.0587)\end{array}$ \\
\hline \multicolumn{4}{|l|}{ Dependent variable: $\Delta I M M^{\text {shr }}$} \\
\hline$\widetilde{\Delta P W}^{C h n}$ & $\begin{array}{c}0.0383^{* *} \\
(0.0164)\end{array}$ & $\begin{array}{c}0.0031898 \\
(0.0036)\end{array}$ & $\begin{array}{l}-0.0022 \\
(0.0423)\end{array}$ \\
\hline$I M M^{s h r}, t-7$ & $\begin{array}{c}0.8781^{* * *} \\
(0.0491)\end{array}$ & $\begin{array}{c}0.4357^{* * *} \\
(0.0277)\end{array}$ & $\begin{array}{c}1.0036^{* * *} \\
(0.1349)\end{array}$ \\
\hline Additional controls & yes & yes & yes \\
\hline Regional (NUTS2) controls & yes & yes & yes \\
\hline Region (NUTS2) fixed effects & yes & yes & yes \\
\hline Year fixed effects & yes & yes & yes \\
\hline Observations & 1,562 & 16,039 & 218 \\
\hline Kleibergen-Paap F & 106.65 & 123.66 & 3.09 \\
\hline Fixed effects model & LMA & Municipality & Province \\
\hline \multicolumn{4}{|l|}{ Dependent variable: $I P W^{C h n}$} \\
\hline$\widetilde{I P W}^{C h n}$ & $\begin{array}{c}0.2461^{* * *} \\
(0.0468)\end{array}$ & $\begin{array}{c}0.1635^{* * *} \\
(0.0335)\end{array}$ & $\begin{array}{c}0.2887^{* *} \\
(0.1310)\end{array}$ \\
\hline$I M M^{s h r}, t-5$ & $\begin{array}{c}0.3024^{* * *} \\
(0.0533)\end{array}$ & $\begin{array}{c}0.1763^{* * *} \\
(0.0204)\end{array}$ & $\begin{array}{c}0.3307^{* * *} \\
(0.1120)\end{array}$ \\
\hline \multicolumn{4}{|l|}{ Dependent variable: IMM $M^{\text {shr }}$} \\
\hline$\widetilde{I P W}^{C h n}$ & $\begin{array}{c}0.0138 \\
(0.0135)\end{array}$ & $\begin{array}{c}0.0097^{* *} \\
(0.0039)\end{array}$ & $\begin{array}{c}0.0005 \\
(0.0260)\end{array}$ \\
\hline$I M M^{s h r}, t-5$ & $\begin{array}{c}1.4553^{* * *} \\
(0.0643)\end{array}$ & $\begin{array}{c}0.8839^{* * *} \\
(0.0446)\end{array}$ & $\begin{array}{c}1.5950^{* * *} \\
(0.1399)\end{array}$ \\
\hline Additional controls & yes & yes & yes \\
\hline Regional (NUTS2) controls & yes & yes & yes \\
\hline Level fixed effects & yes & yes & yes \\
\hline Year fixed effects & yes & yes & yes \\
\hline Observations & 2,052 & 24,071 & 317 \\
\hline Kleibergen-Paap F & 17.42 & 127.12 & 2.69 \\
\hline
\end{tabular}

Notes: The additional controls include number of residents, share of residents above 65 in the adult population, share of residents with primary or lower secondary education, share of residents with tertiary education, unemployment rate, labor force participation rate and value added per worker at each level of aggregation. The regional controls include hospital migration, informal labor, share of expenditure on cultural activities, tickets in cultural activities per capita, volunteering, attractiveness of universities and internet diffusion. Standard errors clustered at each level of aggregation are shown in parentheses. * ${ }^{\star \star}$ and ${ }^{\star \star \star}$ indicate coefficients significantly different from zero at the $10 \%, 5 \%$ and $1 \%$ level respectively.

Regarding the validity of these instruments, as all models are just identified, we rely on previous research making use of them, in particular Autor et al. (2013) and Otto and to be informative even in this case. 
Table 5: First-difference model - IV estimates

\begin{tabular}{|c|c|c|c|c|c|}
\hline & $\begin{array}{c}(1) \\
\Delta \text { FarRight }\end{array}$ & $\begin{array}{c}(2) \\
\Delta \text { FarLeft }\end{array}$ & $\begin{array}{c}(3) \\
\Delta \text { Right-wing }\end{array}$ & $\begin{array}{c}(4) \\
\Delta T A N\end{array}$ & $\begin{array}{c}(5) \\
\Delta \text { Turnout }\end{array}$ \\
\hline$\Delta I P W^{C h n}$ & $\begin{array}{c}0.668^{* *} \\
(0.270)\end{array}$ & $\begin{array}{l}-0.080 \\
(0.103)\end{array}$ & $\begin{array}{c}0.251 \\
(0.253)\end{array}$ & $\begin{array}{c}0.186 \\
(0.206)\end{array}$ & $\begin{array}{l}-0.282 \\
(0.261)\end{array}$ \\
\hline$\Delta I M M^{s h r}$ & $\begin{array}{c}0.893^{* * *} \\
(0.242)\end{array}$ & $\begin{array}{c}0.190^{* * * *} \\
(0.056)\end{array}$ & $\begin{array}{c}1.205^{* * *} \\
(0.179)\end{array}$ & $\begin{array}{c}0.655^{* * *} \\
(0.142)\end{array}$ & $\begin{array}{c}-0.558^{* * *} \\
(0.162)\end{array}$ \\
\hline LMA controls & yes & yes & yes & yes & yes \\
\hline Regional (NUTS2) controls & yes & yes & yes & yes & yes \\
\hline Region (NUTS2) fixed effects & yes & yes & yes & yes & yes \\
\hline Year fixed effects & yes & yes & yes & yes & yes \\
\hline $2 \mathrm{SLS}$ & yes & yes & yes & yes & yes \\
\hline Observations & 1,562 & 1,562 & 1,562 & 1,562 & 1,562 \\
\hline R-squared & 0.422 & 0.567 & 0.610 & 0.418 & 0.442 \\
\hline Kleibergen-Paap F & 106.65 & 106.65 & 106.65 & 106.65 & 106.65 \\
\hline
\end{tabular}

Notes: The dependent variable in columns (1) through (4) is the percentage point change in the votes for each group of parties (far right, far left, right-wing, traditional/authoritarian/nationalist) and in column (5) the percentage point change in voters' turnout. The 2SLS specifications instrument for the change in Chinese imports in Italy using the change in other developed countries' imports from China and for the change in the immigrants using the value at the beginning of the period. The LMA controls include number of residents, share of residents above 65 in the adult population, share of residents with primary or lower secondary education, share of residents with tertiary education, unemployment rate, labor force participation rate and value added per worker. The regional controls include hospital migration, informal labor, share of expenditure on cultural activities, tickets in cultural activities per capita, volunteering, attractiveness of universities and internet diffusion. Standard errors clustered at the LMA level are shown in parentheses. ${ }^{\star \star}$ and ${ }^{\star \star \star}$ indicate coefficients significantly different from zero at the $5 \%$ and $1 \%$ level respectively.

Steinhardt (2014), as discussed in Section 3.5.

The second-stage results of the 2SLS regressions are reported in Table 5 and Table 6. While the 2SLS estimates seem to be generally in line in qualitative terms with the OLS estimates that assume no endogenety issues, a few key differences emerge. The main difference lies in a generalized loss of statistical significance for the coefficients on Chinese import competition in all regressions except that looking at the share of votes for the extreme right, especially in the mixed first-difference model. Another important difference concerns the fact that the coefficient on immigrant share becomes positive and significant in the regression for the vote share for far-right and far-left parties in the mixed first-difference model. Moreover, the coefficient on immigrant share becomes not significantly different from zero in the regression on the vote share for far-left parties in 
Table 6: Fixed effects model - IV estimates

\begin{tabular}{|c|c|c|c|c|c|}
\hline & $\begin{array}{c}(1) \\
\text { FarRight }\end{array}$ & $\begin{array}{c}(2) \\
\text { FarLeft }\end{array}$ & $\begin{array}{c}(3) \\
\text { Right-wing }\end{array}$ & $\begin{array}{c}(4) \\
T A N\end{array}$ & $\begin{array}{c}(5) \\
\text { Turnout }\end{array}$ \\
\hline$I P W^{C h n}$ & $\begin{array}{c}0.683^{* *} \\
(0.290)\end{array}$ & $\begin{array}{l}-0.219 \\
(0.141)\end{array}$ & $\begin{array}{l}0.526^{*} \\
(0.286)\end{array}$ & $\begin{array}{c}0.001 \\
(0.195)\end{array}$ & $\begin{array}{l}-0.031 \\
(0.217)\end{array}$ \\
\hline$I M M^{s h r}$ & $\begin{array}{c}2.004^{* * *} \\
(0.302)\end{array}$ & $\begin{array}{l}-0.004 \\
(0.075)\end{array}$ & $\begin{array}{c}1.208^{* * *} \\
(0.281)\end{array}$ & $\begin{array}{c}0.677^{* * *} \\
(0.160)\end{array}$ & $\begin{array}{c}-1.692^{* * *} \\
(0.229)\end{array}$ \\
\hline LMA controls & yes & yes & yes & yes & yes \\
\hline Regional (NUTS2) controls & yes & yes & yes & yes & yes \\
\hline LMA fixed effects & yes & yes & yes & yes & yes \\
\hline Year fixed effects & yes & yes & yes & yes & yes \\
\hline 2SLS & yes & yes & yes & yes & yes \\
\hline Observations & 2,052 & 2,052 & 2,052 & 2,052 & 2,052 \\
\hline R-squared & 0.579 & 0.805 & 0.330 & 0.277 & 0.442 \\
\hline Kleibergen-Paap F & 17.42 & 17.42 & 17.42 & 17.42 & 17.42 \\
\hline
\end{tabular}

Notes: The dependent variable in columns (1) through (4) is the percentage of votes for each group of parties (far right, far left, right-wing, traditional/authoritarian/nationalist) and in column (5) the percentage value for voters' turnout. The 2SLS specifications instrument for Chinese imports in Italy using other developed countries' imports from China and for the share of immigrants using its five-year lag. The LMA controls include number of residents, share of residents above 65 in the adult population, share of residents with primary or lower secondary education, share of residents with tertiary education, unemployment rate, labor force participation rate and value added per worker. The regional controls include hospital migration, informal labor, share of expenditure on cultural activities, tickets in cultural activities per capita, volunteering, attractiveness of universities and internet diffusion. Standard errors clustered at the LMA level are shown in parentheses. ${ }^{\star},{ }^{\star \star}$ and ${ }^{\star \star \star}$ indicate coefficients significantly different from zero at the $10 \%, 5 \%$ and $1 \%$ level respectively.

the fixed effects model.

With regards to the size of the 2SLS coefficients relative to the OLS estimates, one can observe that the bias of the OLS estimates in the fixed effects model is relatively small and there appears to be no clear pattern. On the other hand, it is possible to notice a larger bias with a clearer pattern for the OLS estimates in the mixed first-difference model. This difference seems to suggest that the fixed effects model is better able to control for unobserved heterogeneity as it is more consistent across different specifications. Regarding the bias in the mixed first-difference model, there is a substantial upward bias in the OLS coefficients on changes in Chinese imports per worker, which are up to twice as large as the corresponding 2SLS estimates, and a substantial downward bias in the OLS coefficients on changes in immigrants per resident, which are on average half the size of the 2SLS estimates. The upward bias of the OLS estimates of the effects of Chinese import 
competition seems to imply that these estimates are picking up not only Chinese supply shocks but also other shocks that may push up the vote share of far-right parties, e.g., negative domestic sectoral supply shocks. It is interesting to notice that this bias runs in the opposite direction compared to that found in other papers studying the effects of import competition on electoral outcomes in other countries, such as Autor et al. (2016), Malgouyres (2017) and Dippel et al. (2017), in which import competition partly reflects domestic sectoral demand shifts. The downward bias of the OLS estimates of the effects of immigration is in line with that found in other papers (Barone et al., 2016; Otto and Steinhardt, 2014) and migrants choose to locate where the local population is more open toward them or the local labor market is stronger.

Next, we discuss in detail the quantitative effects of the 2SLS estimates. The 2SLS estimates for the effects of Chinese import competition and immigration on the percentage of votes going to far-right parties are reported in column (1) of Table 5 and of Table 6 . In both models, the vote share for far-right parties is positively affected by both local Chinese import competition and immigration. The size of the coefficients suggests that one standard deviation increase in local Chinese import competition leads to about one percentage point increase in the vote share of far-right parties and this quantitative effect is similar across the two models despite all their differences described above. On the other hand, an increase in the percentage of immigrants per resident by one standard deviation has a much larger effect in the fixed effects model, where it leads to an increase by more than five percentage points in the vote share of far-right parties, than in the mixed firstdifference model, where the effect is roughly equal to an increase by two percentage points in the vote share of far-right parties. This is a politically significant outcome as in Italy far-right parties have on average obtained $15 \%$ of the votes over the period analysed.

The effects of immigration and import shocks on the electoral performance of far-left parties are reported in column (2) of Table 5 and of Table 6 . The 2SLS estimates show that only immigration in the mixed first-difference model has a significant and positive effect on the vote share of far-left parties. The size of the coefficient suggests that an 
increase in the percentage of immigrants per resident by one standard deviation increases the vote share of far-left parties by about half a percentage point. We may interpret this result in the following way. When immigration becomes more conspicuous, electors that value social inclusion may decide to vote for far-left parties, which has usually been sensitive to immigration issues (e.g., by promoting campaigns against racism and xenophobia). Taken together with the positive effect of immigration on the far right, this result provides some evidence of an ideological polarization of the electors in the face of local immigration shocks. The insignificant effect of Chinese import competition on far-left parties could be due to the fact that leftist parties around the world are seen as either pro-trade or, at least, not anti-trade, even though they generally run campaigns against the so-called 'neoliberal paradigm', whereas right-wing parties are seen as being more protectionist. ${ }^{31}$

Moving away from the analysis of political extremes, column (3) of Table 5 and of Table 6 shows the results of 2SLS regressions on the share of votes for Italian right-wing parties. In line with Barone et al. (2016), we find a positive and significant effect of immigration on the vote share of right-wing parties in both models. The size of the coefficients suggests that the magnitude of the effect is similar across models and implies that an increase by one standard deviation in the percentage of immigrants per resident leads to an increase in the vote share of right-wing parties by about three percentage points. On the other hand, we do not find robust evidence of an effect of Chinese import competition on the electoral performance of right-wing parties (the coefficient in the fixed effects model is positive and significant only at the $10 \%$ level). By changing the signs of the coefficients, the results of columns (3) can be interpreted as the effects produced by globalization on the vote share of parties belonging to the center-left. Therefore, the results show that center-left parties are penalized by higher immigration.

\footnotetext{
${ }^{31}$ This pro-trade orientation of leftist parties might have started changing around the world, as suggested for instance by the emergence of anti-globalization movements within the Democratic Party in the US and Labour in the UK. No such phenomenon is apparent in Italy, possibly because most leftist parties differentiate their positions with regards to the Economic and Monetary Union rather than global trade.
} 
Column (4) of Table 5 and of Table 6 presents the estimates of the effects of our proxies for globalization on the electoral performances of TAN parties. In both models, TAN parties respond only to changes in the local intensity of immigration while they do not seem to be affected by the dynamics of import competition. The size of the coefficients shows that an increase by one standard deviation in the percentage of immigrants per resident is associated with an increase in the vote share for TAN parties by about one and a half percentage points. Even though the overlap between right-wing and TAN parties is only partial (as some centre- and left-wing parties belong to this group due to their conservative stance in terms of cultural identity), the results are qualitatively similar. Yet, contrary to the results for right-wing parties, the coefficient of import competition in this case is never close to conventional levels of statistical significance. This is probably due to the inclusion in the TAN group of some centre- and left-wing parties leaning in favor of international trade.

Finally, column (5) of Table 5 and of Table 6 reports the estimates of the effects of Chinese import competition and immigration on voters' turnout. According to our models, both import competition and immigration have a negative effect on the percentage of residents that exercise their right to vote, but only the effect of immigration is significant. The size of the coefficients on immigration implies that an increase in the percentage of immigrants per resident by one standard deviation leads to a decrease in voters' turnout by almost five percentage points in the fixed effects model, while the magnitude of the effect is much smaller in the mixed first-difference model (just over one percentage point). If the presence of immigrants increases natives' sense of insecurity (Hainmueller and Hiscox, 2010; Kriesi et al., 2006), which, in turn, reduces trust towards political parties as well as political involvement, then the negative impact of the share of immigrants on the electoral turnout can be explained following the reasoning of Guiso et al. (2017). Following their argument, one may argue that the majority of those who have decided not to vote would have otherwise voted for parties classified as far-right in the present analysis or so-called populist parties following their classification. 
To recap, the results show that both import competition and immigration contributed to the electoral success of far-right parties. On the other hand, only immigration appears to have supported the success of right-wing and traditionalist/authoritarian/nationalist parties. These different effects can be potentially explained by the political stance of moderate right-wing parties (not part of the far-right parties) and moderate left-wing parties (also part of the traditionalist/authoritarian/nationalist parties). While these parties shared the same concerns about immigration as far-right parties and captured some voters interested in this issue, they also embraced international trade, thus leaving this second issue to far-right parties only. Depending on the model, the results show that immigration may have also increased the vote share of far-left parties and, thus, led to an increase in political polarization. Finally, we find that electoral turnout decreased in response to immigration.

\subsection{The role of labor market controls}

Considering that other factors beyond import competition and immigration may influence both electoral outcomes and labor market dynamics, we include the unemployment rate, the labor force participation rate and value added per worker among the LMA controls in all previous specifications. Consider the following example to appreciate the motivations to include such controls. Imagine that a large company in a growing demand sector goes bankrupt for idiosyncratic reasons and sheds workers. One would then observe an increase in the local unemployment rate that is spuriously correlated with the growth of imports and causally related to certain local electoral outcomes. To control for this possibility, the inclusion of labor market controls in our estimations is recommendable.

Yet, this is a conservative approach. Indeed, the inclusion of variables related to labor market dynamics implies that our estimates of the coefficients for the proxies of globalization may not account for the total effects of globalization on electoral outcomes. Some effects mediated via the functioning of local labor markets would instead be captured by such controls. Thus, if the effects of globalization on electoral outcomes were mainly 
Table 7: First-difference model - IV estimates without labor market controls

\begin{tabular}{|c|c|c|c|c|c|}
\hline & $\begin{array}{c}(1) \\
\Delta \text { FarRight }\end{array}$ & $\begin{array}{c}(2) \\
\Delta \text { FarLeft }\end{array}$ & $\begin{array}{c}(3) \\
\Delta \text { Right-wing }\end{array}$ & $\begin{array}{c}(4) \\
\Delta T A N\end{array}$ & $\begin{array}{c}(5) \\
\Delta \text { Turnout }\end{array}$ \\
\hline$\Delta I P W^{C h n}$ & $\begin{array}{c}1.235^{* * *} \\
(0.298)\end{array}$ & $\begin{array}{l}-0.027 \\
(0.104)\end{array}$ & $\begin{array}{c}0.725^{* * *} \\
(0.266)\end{array}$ & $\begin{array}{c}0.594^{* * *} \\
(0.214)\end{array}$ & $\begin{array}{l}-0.357 \\
(0.257)\end{array}$ \\
\hline$\Delta I M M^{s h r}$ & $\begin{array}{c}1.538^{* * *} \\
(0.266)\end{array}$ & $\begin{array}{c}0.257^{* * *} \\
(0.058)\end{array}$ & $\begin{array}{c}1.694^{* * *} \\
(0.214)\end{array}$ & $\begin{array}{c}1.047^{* * *} \\
(0.165)\end{array}$ & $\begin{array}{c}-0.635^{* * *} \\
(0.158)\end{array}$ \\
\hline LMA controls (w/o labor market) & yes & yes & yes & yes & yes \\
\hline Regional (NUTS2) controls & yes & yes & yes & yes & yes \\
\hline Region (NUTS2) fixed effects & yes & yes & yes & yes & yes \\
\hline Year fixed effects & yes & yes & yes & yes & yes \\
\hline 2SLS & yes & yes & yes & yes & yes \\
\hline Observations & 1,562 & 1,562 & 1,562 & 1,562 & 1,562 \\
\hline R-squared & 0.294 & 0.554 & 0.535 & 0.336 & 0.438 \\
\hline Kleibergen-Paap F & 98.48 & 98.48 & 98.48 & 98.48 & 98.48 \\
\hline
\end{tabular}

Notes: The dependent variable in columns (1) through (4) is the percentage point change in the votes for each group of parties (far right, far left, right-wing, traditional/authoritarian/nationalist) and in column (5) the percentage point change in voters' turnout. The 2SLS specifications instrument for the change in Chinese imports in Italy using the change in other developed countries' imports from China and for the change in the immigrants using the value at the beginning of the period. The LMA controls include number of residents, share of residents above 65 in the adult population, share of residents with primary or lower secondary education and share of residents with tertiary education. The regional controls include hospital migration, informal labor, share of expenditure on cultural activities, tickets in cultural activities per capita, volunteering, attractiveness of universities and internet diffusion. Standard errors clustered at the LMA level are shown in parentheses. ${ }^{\star \star \star}$ indicates coefficients significantly different from zero at the $1 \%$ level.

driven by labor market dynamics, the inclusion of labor market controls would lead to lower estimated coefficients. Hence, to gain some insight into the mediating role of local labor markets, we estimate our models without the above-mentioned controls. ${ }^{32}$

Table 7 and Table 8 report the results of these additional specifications. As we exclude labor market controls, all point estimates in the mixed first-difference model increase albeit not in a significant way, with the exception of the coefficients on changes in Chinese imports per worker that become statistically different from zero in the regressions

\footnotetext{
${ }^{32}$ In the main specifications above, we include not only labor controls, but also several other covariates because the exclusion restrictions for our endogenous variables are likely to hold only conditionally on them. However, the inclusion of potentially post-treatment controls may not only block some causal paths, but it may also introduce bias if the variables are themselves endogenous (Montgomery et al., 2018). Therefore, as a robustness check, in Appendix B, we also show two tables of results based on the above IV specifications, but with the exclusion of all covariates. All the main results go through as in most cases the coefficients on the China share and the immigration share do not differ in a statistically significant way.
} 
Table 8: Fixed effects model - IV estimates without labor market controls

\begin{tabular}{|c|c|c|c|c|c|}
\hline & $\begin{array}{c}(1) \\
\text { FarRight }\end{array}$ & $\begin{array}{c}(2) \\
\text { FarLeft }\end{array}$ & $\begin{array}{c}(3) \\
\text { Right-wing }\end{array}$ & $\begin{array}{c}(4) \\
T A N\end{array}$ & $\begin{array}{c}(5) \\
\text { Turnout }\end{array}$ \\
\hline$I P W^{C h n}$ & $\begin{array}{c}0.647^{* *} \\
(0.276)\end{array}$ & $\begin{array}{l}-0.218 \\
(0.145)\end{array}$ & $\begin{array}{c}0.415 \\
(0.270)\end{array}$ & $\begin{array}{l}-0.030 \\
(0.195)\end{array}$ & $\begin{array}{l}-0.014 \\
(0.241)\end{array}$ \\
\hline$I M M^{s h r}$ & $\begin{array}{c}2.045^{* * *} \\
(0.295)\end{array}$ & $\begin{array}{c}0.023 \\
(0.078)\end{array}$ & $\begin{array}{c}1.341^{* * *} \\
(0.270)\end{array}$ & $\begin{array}{c}0.805^{* * *} \\
(0.154)\end{array}$ & $\begin{array}{c}-1.424^{* * *} \\
(0.223)\end{array}$ \\
\hline LMA controls (w/o labor market) & yes & yes & yes & yes & yes \\
\hline Regional (NUTS2) controls & yes & yes & yes & yes & yes \\
\hline LMA fixed effects & yes & yes & yes & yes & yes \\
\hline Year fixed effects & yes & yes & yes & yes & yes \\
\hline 2SLS & yes & yes & yes & yes & yes \\
\hline Observations & 2,052 & 2,052 & 2,052 & 2,052 & 2,052 \\
\hline R-squared & 0.572 & 0.802 & 0.319 & 0.264 & 0.417 \\
\hline Kleibergen-Paap F & 16.44 & 16.44 & 16.44 & 16.44 & 16.44 \\
\hline
\end{tabular}

Notes: The dependent variable in columns (1) through (4) is the percentage of votes for each group of parties (far right, far left, right-wing, traditional/authoritarian/nationalist) and in column (5) the percentage value for voters' turnout. The 2SLS specifications instrument for Chinese imports in Italy using other developed countries' imports from China and for the share of immigrants using its five-year lag. The LMA controls include number of residents, share of residents above 65 in the adult population, share of residents with primary or lower secondary education and share of residents with tertiary education. The regional controls include hospital migration, informal labor, share of expenditure on cultural activities, tickets in cultural activities per capita, volunteering, attractiveness of universities and internet diffusion. Standard errors clustered at the LMA level are shown in parentheses. ${ }^{\star \star}$ and ${ }^{\star \star \star}$ indicate coefficients significantly different from zero at the $5 \%$ and $1 \%$ level respectively.

for right-wing and TAN parties. On the other hand, only some point estimates in the fixed effects model increase and their changes in general are relatively small in magnitude. This difference in results provides some further evidence of the fact that the fixed effects model seems to be more robust to different specifications. Yet, in general, the results do not seem to change substantially and this could be due to two different reasons. First, our labor market controls are not exhaustive: other variables that may be much more relevant in explaining the linkages between labor market dynamics and voting behavior, such as average wages, income inequality and job security, have not been included in our specifications because of lack of available data. ${ }^{33}$ Second, the effects of globalization on electoral outcomes may work not only through the functioning of labor markets but also via other channels, as suggested by those scholars focusing on identity and culture (see,

\footnotetext{
${ }^{33}$ By the same token, as recently shown by Gimpelson and Treisman (2018), perceived inequality may differ from actual inequality, thereby adding a further subjective dimension to this issue.
} 
for instance, Inglehart and Norris, 2016). This is further investigated in the following section.

\subsection{Alternative units of analysis}

As previously argued, if the effects of immigration and import competition on electoral outcomes are mainly mediated by the dynamics of local labor markets, LMAs represent the most appropriate unit of analysis. Since other transmission channels may be at work too, it is interesting to explore how the results are affected by changes in the level of geographical aggregation of the analytical units. Indeed, even though the transmission channels cannot be directly identified, the sensitivity of the estimates to the narrowing and to the expansion of the geographical boundaries of the units of analysis can provide meaningful insights about the level at which such channels operate. It should be noticed that it is not obvious to determine how the results change at different levels of aggregation because a lower level of aggregation is associated with both an increase in the sample size, which also affects the significance of the coefficients including those of the first stage, and a potential increase in spillover effects.

Next, we estimate our two models at both a more disaggregated level, i.e., municipalities, and a more aggregated level, i.e., provinces (NUTS3). More precisely, we estimate two variations of equations 3 and 4 , where the subscript $i$ indicates either a municipality or a province instead of a LMA. Accordingly, also the set of controls $\boldsymbol{x}_{i}$ and the fixed effects $\phi_{i}$ refer to the new analytical units.

Table 9 and Table 10 show the results of the regressions at the level of municipalities. Overall, all the coefficients that were significant in the LMA-level regressions maintain their signs and the level of significance increases, except for the coefficient on changes in immigrants per resident in the regression for voters' turnout. In addition, the coefficients on Chinese import competition in the regressions for the vote share of right-wing and TAN parties (with positive signs) and voters' turnout (with a negative sign) become significant in both models. Regarding the size of the coefficients and the magnitude of the effects 
Table 9: First-difference model, municipality level - IV estimates

\begin{tabular}{|c|c|c|c|c|c|}
\hline & $\begin{array}{c}(1) \\
\Delta \text { FarRight }\end{array}$ & $\begin{array}{c}(2) \\
\Delta \text { FarLeft }\end{array}$ & $\begin{array}{c}(3) \\
\Delta \text { Right-wing }\end{array}$ & $\begin{array}{c}(4) \\
\Delta T A N\end{array}$ & $\begin{array}{c}(5) \\
\Delta \text { Turnout }\end{array}$ \\
\hline$\Delta I P W^{C h n}$ & $\begin{array}{c}0.233^{* * *} \\
(0.058)\end{array}$ & $\begin{array}{l}-0.028 \\
(0.022)\end{array}$ & $\begin{array}{c}0.139^{* *} \\
(0.069)\end{array}$ & $\begin{array}{c}0.085^{* *} \\
(0.043)\end{array}$ & $\begin{array}{c}-0.162^{* *} \\
(0.067)\end{array}$ \\
\hline$\Delta I M M^{s h r}$ & $\begin{array}{c}1.146^{* * *} \\
(0.109)\end{array}$ & $\begin{array}{c}0.131^{* * *} \\
(0.034)\end{array}$ & $\begin{array}{c}1.282^{* * *} \\
(0.103)\end{array}$ & $\begin{array}{c}0.955^{* * *} \\
(0.091)\end{array}$ & $\begin{array}{l}-0.066 \\
(0.089)\end{array}$ \\
\hline Municipality controls & yes & yes & yes & yes & yes \\
\hline Regional (NUTS2) controls & yes & yes & yes & yes & yes \\
\hline Region (NUTS2) fixed effects & yes & yes & yes & yes & yes \\
\hline Year fixed effects & yes & yes & yes & yes & yes \\
\hline 2SLS & yes & yes & yes & yes & yes \\
\hline Observations & 16,039 & 16,039 & 16,039 & 16,039 & 16,039 \\
\hline R-squared & 0.295 & 0.309 & 0.337 & 0.268 & 0.277 \\
\hline Kleibergen-Paap F & 123.66 & 123.66 & 123.66 & 123.66 & 123.66 \\
\hline
\end{tabular}

Notes: The dependent variable in columns (1) through (4) is the percentage point change in the votes for each group of parties (far right, far left, right-wing, traditional/authoritarian/nationalist) and in column (5) the percentage point change in voters' turnout. The 2SLS specifications instrument for the change in Chinese imports in Italy using the change in other developed countries' imports from China and for the change in the immigrants using the value at the beginning of the period. The municipality controls include number of residents, share of residents above 65 in the adult population, share of residents with primary or lower secondary education, share of residents with tertiary education, unemployment rate, labor force participation rate and value added per worker. The regional controls include hospital migration, informal labor, share of expenditure on cultural activities, tickets in cultural activities per capita, volunteering, attractiveness of universities and internet diffusion. Standard errors clustered at the municipality level are shown in parentheses. ${ }^{\star \star}$ and ${ }^{\star \star \star}$ indicate coefficients significantly different from zero at the $5 \%$ and $1 \%$ level respectively.

on electoral outcomes of an increase in either globalization variable, it is interesting to notice that the effects of Chinese import competition become smaller relative to the equivalent effects found using local labor markets as units of analysis, while they generally increase for immigration, with the exception of the regression for voters' turnout. ${ }^{34}$ All these patterns appear to be stronger in the mixed first-difference model. ${ }^{35}$ Therefore, it appears that labor market effects are an important component of our results, especially

\footnotetext{
${ }^{34}$ At the municipality level for the periods analyzed, the standard deviation of changes in Chinese imports per worker is 1.863 , the standard deviation of changes in immigrants per resident is 2.824 , the standard deviation of the level of Chinese imports per worker is 1.907 and the standard deviation of the level of in immigrants per resident is 3.639 .

${ }^{35}$ It should be noticed that the difference in results across different units of analysis should not be simply due to different degrees of measurement error because the size of the coefficients and their significance do not move in a unique direction for all variables and models. Moreover, based on the first-stage regressions, even though the instruments seem to become less informative when we use more aggregated analytical units, they are always significant and the size of the first-stage coefficients actually increases as we move toward more aggregated analytical units.
} 
Table 10: Fixed effects model, municipality level - IV estimates

\begin{tabular}{|c|c|c|c|c|c|}
\hline & $\begin{array}{c}(1) \\
\text { FarRight }\end{array}$ & $\begin{array}{c}(2) \\
\text { FarLeft }\end{array}$ & $\begin{array}{c}(3) \\
\text { Right-wing }\end{array}$ & $\begin{array}{c}(4) \\
T A N\end{array}$ & $\begin{array}{c}(5) \\
\text { Turnout }\end{array}$ \\
\hline$I P W^{C h n}$ & $\begin{array}{c}0.476^{* * *} \\
(0.087)\end{array}$ & $\begin{array}{l}-0.032 \\
(0.024)\end{array}$ & $\begin{array}{c}0.328^{* * *} \\
(0.061)\end{array}$ & $\begin{array}{c}0.188^{* * * *} \\
(0.046)\end{array}$ & $\begin{array}{c}-0.193^{* * *} \\
(0.065)\end{array}$ \\
\hline$I M M^{\text {shr }}$ & $\begin{array}{c}2.081^{* * *} \\
(0.112)\end{array}$ & $\begin{array}{c}0.040 \\
(0.030)\end{array}$ & $\begin{array}{c}0.804^{* * *} \\
(0.079)\end{array}$ & $\begin{array}{c}0.723^{* * *} \\
(0.069)\end{array}$ & $\begin{array}{c}-1.062^{* * *} \\
(0.094)\end{array}$ \\
\hline Municipality controls & yes & yes & yes & yes & yes \\
\hline Regional (NUTS2) controls & yes & yes & yes & yes & yes \\
\hline Municipality fixed effects & yes & yes & yes & yes & yes \\
\hline Year fixed effects & yes & yes & yes & yes & yes \\
\hline $2 \mathrm{SLS}$ & yes & yes & yes & yes & yes \\
\hline Observations & 24,069 & 24,069 & 24,069 & 24,069 & 24,069 \\
\hline R-squared & 0.232 & 0.623 & 0.241 & 0.127 & 0.244 \\
\hline Kleibergen-Paap F & 127.12 & 127.12 & 127.12 & 127.12 & 127.12 \\
\hline
\end{tabular}

Notes: The dependent variable in columns (1) through (4) is the percentage of votes for each group of parties (far right, far left, right-wing, traditional/authoritarian/nationalist) and in column (5) the percentage value for voters' turnout. The 2SLS specifications instrument for Chinese imports in Italy using other developed countries' imports from China and for the share of immigrants using its five-year lag. The municipality controls include number of residents, share of residents above 65 in the adult population, share of residents with primary or lower secondary education, share of residents with tertiary education, unemployment rate, labor force participation rate and value added per worker. The regional controls include hospital migration, informal labor, share of expenditure on cultural activities, tickets in cultural activities per capita, volunteering, attractiveness of universities and internet diffusion. Standard errors clustered at the municipality level are shown in parentheses. ${ }^{\star \star \star}$ indicates coefficients significantly different from zero at the $1 \%$ level.

for Chinese import competition, but mechanisms other than labor market competition are also at play, especially for immigration. Such additional mechanisms seem to operate at the level of local communities (municipalities) and could be related to concerns that are not about the economic sphere (in its strict sense) but rather regard the social and cultural consequences of globalization as discussed in Margalit (2012) and Inglehart and Norris (2016). Interestingly, these results are driven by the communities with a population below 15 thousand, i.e., where the sense of community is likely to be stronger, while most of the effects (except for those on the far-right parties) disappear in larger urban aggregates. ${ }^{36}$

Table 11 and Table 12 report the results of the mixed first-difference and fixed effects models estimated using NUTS3 provinces as analytical units. At this higher level of aggregation, the effects of Chinese import competition disappear, except for voters'

\footnotetext{
${ }^{36}$ Additional results are available upon request.
} 
Table 11: First-difference model, province level (NUTS3) - IV estimates

\begin{tabular}{|c|c|c|c|c|c|}
\hline & $\begin{array}{c}(1) \\
\Delta \text { FarRight }\end{array}$ & $\begin{array}{c}(2) \\
\Delta \text { FarLeft }\end{array}$ & $\begin{array}{c}(3) \\
\Delta \text { Right-wing }\end{array}$ & $\begin{array}{c}(4) \\
\Delta T A N\end{array}$ & $\begin{array}{c}(5) \\
\Delta \text { Turnout }\end{array}$ \\
\hline $\begin{array}{l}\Delta I P W^{C h n} \\
\Delta I M M^{s h r}\end{array}$ & $\begin{array}{l}0.928 \\
(0.647) \\
1.191^{*} \\
(0.653)\end{array}$ & $\begin{array}{l}-0.265 \\
(0.358) \\
0.326^{*} \\
(0.174)\end{array}$ & $\begin{array}{c}-0.295 \\
(0.709) \\
2.220^{* * *} \\
(0.554)\end{array}$ & $\begin{array}{c}0.452 \\
(0.587) \\
1.066^{* *} \\
(0.495)\end{array}$ & $\begin{array}{c}-0.812^{* *} \\
(0.372) \\
-0.222 \\
(0.350)\end{array}$ \\
\hline $\begin{array}{l}\text { Province controls } \\
\text { Regional (NUTS2) controls } \\
\text { Region (NUTS2) fixed effects } \\
\text { Year fixed effects } \\
\text { 2SLS }\end{array}$ & $\begin{array}{l}\text { yes } \\
\text { yes } \\
\text { yes } \\
\text { yes } \\
\text { yes }\end{array}$ & $\begin{array}{l}\text { yes } \\
\text { yes } \\
\text { yes } \\
\text { yes } \\
\text { yes }\end{array}$ & $\begin{array}{l}\text { yes } \\
\text { yes } \\
\text { yes } \\
\text { yes } \\
\text { yes }\end{array}$ & $\begin{array}{l}\text { yes } \\
\text { yes } \\
\text { yes } \\
\text { yes } \\
\text { yes }\end{array}$ & $\begin{array}{l}\text { yes } \\
\text { yes } \\
\text { yes } \\
\text { yes } \\
\text { yes }\end{array}$ \\
\hline $\begin{array}{l}\text { Observations } \\
\text { R-squared } \\
\text { Kleibergen-Paap F }\end{array}$ & $\begin{array}{c}218 \\
0.576 \\
3.09\end{array}$ & $\begin{array}{c}218 \\
0.783 \\
3.09\end{array}$ & $\begin{array}{c}218 \\
0.684 \\
3.09\end{array}$ & $\begin{array}{c}218 \\
0.574 \\
3.09\end{array}$ & $\begin{array}{c}218 \\
0.488 \\
3.09\end{array}$ \\
\hline
\end{tabular}

Notes: The dependent variable in columns (1) through (4) is the percentage point change in the votes for each group of parties (far right, far left, right-wing, traditional/authoritarian/nationalist) and in column (5) the percentage point change in voters' turnout. The 2SLS specifications instrument for the change in Chinese imports in Italy using the change in other developed countries' imports from China and for the change in the immigrants using the value at the beginning of the period. The province controls include number of residents, share of residents above 65 in the adult population, share of residents with primary or lower secondary education, share of residents with tertiary education, unemployment rate, labor force participation rate and value added per worker. The regional controls include hospital migration, informal labor, share of expenditure on cultural activities, tickets in cultural activities per capita, volunteering, attractiveness of universities and internet diffusion. Standard errors clustered at the province level are shown in parentheses. ${ }^{\star},{ }^{\star \star}$ and ${ }^{\star \star \star}$ indicate coefficients significantly different from zero at the $10 \%, 5 \%$ and $1 \%$ level respectively.

turnout in the first-difference model, where it becomes negative and significant at the $5 \%$ level. On the other hand, the presence of immigrants continues to produce a positive and significant effect, albeit in some cases only at the $10 \%$ level, on the vote shares of far-right, far-left, right-wing and TAN parties in the mixed first-difference model and only on the vote share of far-right parties in the fixed effects model. With regards to the size of the coefficients, it is possible to observe that the point estimates on Chinese import competition tend to increase relative to those using local labor market as analytical units, albeit not in a significant way except in the regression for voters' turnout. On the other hand, the point estimates on immigration are in many cases smaller, with the exception of the regression for the vote share of far-right parties in the fixed effects model. In this case, however, the magnitude of the effect of an increase in the percentage of immigration 
Table 12: Fixed effects model, province level (NUTS3) - IV estimates

\begin{tabular}{|c|c|c|c|c|c|}
\hline & $\begin{array}{c}(1) \\
\text { FarRight }\end{array}$ & $\begin{array}{c}(2) \\
\text { FarLeft }\end{array}$ & $\begin{array}{c}\text { (3) } \\
\text { Right-wing }\end{array}$ & $\begin{array}{c}(4) \\
T A N\end{array}$ & $\begin{array}{c}(5) \\
\text { Turnout }\end{array}$ \\
\hline$I P W^{C h n}$ & $\begin{array}{c}1.029 \\
(0.840)\end{array}$ & $\begin{array}{l}-0.520 \\
(0.413)\end{array}$ & $\begin{array}{c}0.647 \\
(0.819)\end{array}$ & $\begin{array}{c}0.044 \\
(0.476)\end{array}$ & $\begin{array}{l}-0.391 \\
(0.603)\end{array}$ \\
\hline$I M M^{s h r}$ & $\begin{array}{c}2.573^{* * *} \\
(0.974)\end{array}$ & $\begin{array}{c}0.206 \\
(0.185)\end{array}$ & $\begin{array}{c}0.326 \\
(0.446)\end{array}$ & $\begin{array}{c}0.508 \\
(0.361)\end{array}$ & $\begin{array}{l}-0.290 \\
(0.483)\end{array}$ \\
\hline Province controls & yes & yes & yes & yes & yes \\
\hline Regional (NUTS2) controls & yes & yes & yes & yes & yes \\
\hline Province fixed effects & yes & yes & yes & yes & yes \\
\hline Year fixed effects & yes & yes & yes & yes & yes \\
\hline 2SLS & yes & yes & yes & yes & yes \\
\hline Observations & 314 & 314 & 314 & 314 & 314 \\
\hline R-squared & 0.688 & 0.918 & 0.500 & 0.473 & 0.511 \\
\hline Kleibergen-Paap F & 2.69 & 2.69 & 2.69 & 2.69 & 2.69 \\
\hline
\end{tabular}

Notes: The dependent variable in columns (1) through (4) is the percentage of votes for each group of parties (far right, far left, right-wing, traditional/authoritarian/nationalist) and in column (5) the percentage value for voters' turnout. The 2SLS specifications instrument for Chinese imports in Italy using other developed countries' imports from China and for the share of immigrants using its five-year lag. The province controls include number of residents, share of residents above 65 in the adult population, share of residents with primary or lower secondary education, share of residents with tertiary education, unemployment rate, labor force participation rate and value added per worker. The regional controls include hospital migration, informal labor, share of expenditure on cultural activities, tickets in cultural activities per capita, volunteering, attractiveness of universities and internet diffusion. Standard errors clustered at the province level are shown in parentheses. ${ }^{\star \star \star}$ indicates coefficients significantly different from zero at the $1 \%$ level.

by one standard deviation is about five percentage points, which is similar to that found using local labor markets and municipalities as units of analysis.

Taken together, these results suggest that the transmission channels linking local exposure to globalization and local electoral outcomes are based on social and economic dynamics that work primarily at the level of local communities, especially with respect to the effects of immigration. This is either because additional mechanisms beyond labor market competition are at play or labor market dynamics do not cancel out at lower levels of aggregation. ${ }^{37}$

These findings are of interest both for scholars and party politics. As to the former,

\footnotetext{
${ }^{37}$ Indeed, the impact of globalization may be stronger at the local level or more effective in influencing the electorate. As observed by Gimpelson and Treisman (2018), individuals tend to over-generalize from their immediate reference group and this leads to widespread misconceptions about the actual extent of inequality. Similarly, politically-relevant misconceptions about labor market outcomes might more likely arise in small communities and wash out in the mix in large areas.
} 
they suggest that social scientists studying the recent changes in the political landscape of Western liberal democracies need to choose carefully the level of aggregation of the analysis and would gain considerable insight from more disaggregated data, which is however not available for some countries. As to the latter, they suggest that those political parties concerned with preserving the Italian traditionally open stance vis-á-vis globalization should identify better the diverse channels through which different types of globalization affect voters. It appears of utmost importance to distinguish the effects mediated by local labour markets from those linked to other social channels, as well as those working at low levels of aggregation (e.g., local communities) from those operating at an aggregate level. ${ }^{38}$

\section{Concluding remarks}

The impact that economic phenomena associated with the globalization process have had on political developments and electoral outcomes in the trade-oriented and industrialized Western liberal democracies has recently attracted much attention among economists, political scientists, sociologists, policy advisors and politicians. This work contributes to this rapidly growing literature in that it focuses for on Italy, a large and open G7 country, characterized both by a highly diversified territory along the socio-economic lines and by a lively (to use a euphemism) political system.

More precisely, this work studies to what extent the electoral dynamics in Italy over the 1994-2008 period can be explained by two major phenomena associated with globalization, that is the rising exposure to import competition from China and immigration, once controlling for a number of other socio-economic phenomena. The empirical analysis adopts Italian local labor markets as main unit of analysis, since they make it possible to exploit the large variation associated with the differentiated patterns of industrial

\footnotetext{
${ }^{38}$ Policy responses would need to change accordingly. The European Globalisation Adjustment Fund, which requires countries to demonstrate that job losses follow a substantial increase of imports into the EU, could help to address aggregate, labour markets-related phenomena. Measures directed toward the strengthening of education provisions and redistributive mechanisms may be of greater use at the local level.
} 
specialization (and thus exposure to competition as well) and of immigration across the country.

The analysis focuses on the period before the European sovereign debt crisis and after the dramatic change in the political environment occurred in 1992-1993 that led to the disappearance of most of the traditional parties. Accordingly, it considers the local outcomes at general parliamentary elections in 1994, 2001, 2006 and 2008.

To account for time-invariant unobserved effects across local labor markets, the empirical analysis is based on two alternative models: a mixed first-difference model for the periods 1994-2001 and 2001-2008, and a fixed effects model for the years 2001, 2006 and 2008. Both models are estimated with and without an instrumental variable approach to address possible endogeneity problems, showing the importance of taking these into account.

The empirical analysis suggests that globalization played a relevant role in shaping the local results of Italian general elections in the period 1994-2008. Focusing on the evolution of the share of votes for right-wing, left-wing, traditionalist/authoritarian/nationalist and far-right parties as well as on voters' turnout, the investigation shows that exposure to import competition from China and immigration intensity had an impact that varies across different parties along the Italian political spectrum.

To summarize the results, both globalization-related forces contributed to the electoral success of far-right parties. Only factors related to the local intensity of immigration, instead, appear to have supported the success of right-wing and traditionalist/authoritarian/nationalist parties. Moreover, we find that the electoral turnout responded negatively to an increased presence of migrants, in line with Barone et al. (2016) who find that immigration contributed to a surge of disaffection toward political participation in Italy since 2000 onwards.

Further, the results show some evidence, albeit not too robust, in favour of the hypothesis that the electorate leaning on the far left increased its representation where immigrants grew faster. This finding, together with the clear-cut positive impact of im- 
migration on the electoral results of far-right parties, suggests that immigration is a much stronger polarizing political topic than import competition from China.

Finally, and interestingly, the results, especially for immigration, turn out to be stronger when municipalities, instead of local labor markets, are taken as unit of analysis. This seems to indicate the presence of additional transmission channels other than local labor markets, possibly working at the level of local communities. This could be due to two reasons. On the one hand, in line with the argument of Margalit (2012) and Inglehart and Norris (2016), globalization, and in particular immigration, may influence political preferences also through mechanisms that are not necessarily associated with labor market competition. On the other hand, labor market dynamics do not wash out at lower levels of aggregation. This remains an open question for future research.

\section{References}

Accetturo, A., Manaresi, F., Mocetti, S., and Olivieri, E. (2014). Don't stand so close to me: The urban impact of immigration. Regional Science and Urban Economics, 45:45-56.

Amighini, A., Leone, M., and Rabellotti, R. (2011). Persistence versus Change in the International Specialization Pattern of Italy: How Much Does the 'District Effect' Matter? Regional Studies, 45(3):381-401.

Angrist, J. D. and Krueger, A. B. (2001). Instrumental Variables and the Search for Identification: From Supply and Demand to Natural Experiments. Journal of Economic Perspectives, 15(4):69-85.

Arzheimer, K. (2012). Electoral sociology: Who votes for the extreme right and why and when? In Backes, U. and Moreau, P., editors, The Extreme Right in Europe. Current Trends and Perspectives. Goettingen: Vandenhoeck and Ruprecht.

Autor, D., Dorn, D., Hanson, G., and Majlesi, K. (2016). Importing Political Polarization? The Electoral Consequences of Rising Trade Exposure. NBER Working Papers 22637, National Bureau of Economic Research, Inc.

Autor, D. H., Dorn, D., and Hanson, G. H. (2013). The china syndrome: Local labor market effects of import competition in the united states. American Economic Review, 103(6):2121-68.

Autor, D. H., Dorn, D., Hanson, G. H., and Song, J. (2014). Trade Adjustment: WorkerLevel Evidence. The Quarterly Journal of Economics, 129(4):1799-1860.

Bakker, R., Edwards, E., Hooghe, L., Jolly, S., Marks, G., Polk, J., Rovny, J., Steenbergen, M., and Vachudova, M. (2015). 2014 Chapel Hill Expert Survey (Version 2015.1). University of North Carolina, Chapel Hill.

Barone, G., D'Ignazio, A., de Blasio, G., and Naticchioni, P. (2016). Mr. Rossi, Mr. Hu 
and politics. The role of immigration in shaping natives' voting behavior. Journal of Public Economics, 136(C):1-13.

Barr, R. R. (2009). Populists, outsiders and anti-establishment politics. Party Politics, $15(1): 29-48$.

Bartik, T. J. (1991). Who Benefits from State and Local Economic Development Policies? Kalamazoo, MI: W.E. Upjohn Institute for Employment Research.

Bearce, D. H. and Hutnick, J. L. (2014). International labor mobility, redistribution, and domestic political liberalization. Economics \& Politics, 26(3):411-430.

Beladi, H., Marjit, S., and Oladi, R. (2018). Does protectionism harm unskilled workers? Economics \& Politics, 30(3):444-450.

Betz, H.-G. (1994). Radical Right-Wing Populism in Western Europe. Palgrave Macmillan US.

Blonigen, B. A. and McGrew, J. (2014). Task routineness and trade policy preferences. Economics \& Politics, 26(3):505-518.

Bordo, M. D. and Rousseau, P. L. (2012). Historical evidence on the finance-trade-growth nexus. Journal of Banking \& Finance, 36(4):1236-1243.

Burgoon, B. (2012). Partisan embedding of liberalism: How trade, investment, and immigration affect party support for the welfare state. Comparative Political Studies, 45(5):606-635.

Caiani, M. and Graziano, P. R. (2016). Varieties of populism: insights from the italian case. Italian Political Science Review/Rivista Italiana di Scienza Politica, 46(2):243-267.

Card, D. (2001). Immigrant inflows, native outflows, and the local labor market impacts of higher immigration. Journal of Labor Economics, 19(1):22-64.

Che, Y., Lu, Y., Pierce, J. R., Schott, P. K., and Tao, Z. (2016). Does trade liberalization with china influence u.s. elections? Working Paper 22178, National Bureau of Economic Research.

Colantone, I. and Stanig, P. (2018a). Global competition and brexit. American Political Science Review, 112(2):201-218.

Colantone, I. and Stanig, P. (2018b). The trade origins of economic nationalism: Import competition and voting behavior in western europe. American Journal of Political Science, forthcoming.

Dippel, C., Gold, R., Heblich, S., and Pinto, R. (2017). Instrumental Variables and Causal Mechanisms: Unpacking The Effect of Trade on Workers and Voters. NBER Working Papers 23209, National Bureau of Economic Research, Inc.

Federico, S. (2014). Industry Dynamics and Competition from Low-Wage Countries: Evidence on Italy. Oxford Bulletin of Economics and Statistics, 76(3):389-410.

Feigenbaum, J. J. and Hall, A. B. (2015). How Legislators Respond to Localized Economic Shocks: Evidence from Chinese Import Competition. The Journal of Politics, 77(4):1012-1030.

Fella, S. and Ruzza, C. (2013). Populism and the fall of the centre-right in italy: The end of the berlusconi model or a new beginning? Journal of Contemporary European Studies, 21(1):38-52.

Gimpelson, V. and Treisman, D. (2018). Misperceiving inequality. Economics 83 Politics, $30(1): 27-54$.

Guiso, L., Herrera, H., Morelli, M., and Sonno, T. (2017). Demand and Supply of 
Populism. CEPR Discussion Papers 11871, C.E.P.R. Discussion Papers.

Hainmueller, J. and Hiscox, M. J. (2010). Attitudes toward Highly Skilled and Low-skilled Immigration: Evidence from a Survey Experiment. American Political Science Review, 104(01):61-84.

Hainmueller, J. and Hopkins, D. J. (2014). Public attitudes toward immigration. Annual Review of Political Science, 17(1):225-249.

Halla, M., Wagner, A. F., and Zweimüller, J. (2017). Immigration and voting for the far right. Journal of the European Economic Association, 15(6):1341-1385.

Hanson, G. H., Scheve, K., and Slaughter, M. J. (2007). Public Finance And Individual Preferences Over Globalization Strategies. Economics and Politics, 19(1):1-33.

Helpman, E., Itskhoki, O., and Redding, S. (2010). Inequality and unemployment in a global economy. Econometrica, 78(4):1239-1283.

Hernandez, E. and Kriesi, H. P. (2016). The electoral consequences of the financial and economic crisis in Europe. European Journal of Political Research, 55(2):203-224.

Hooghe, L. and Marks, G. (2018). Cleavage theory meets Europe's crises: Lipset, Rokkan, and the transnational cleavage. Journal of European Public Policy, 25(1):109-135.

Inglehart, R. F. and Norris, P. (2016). Trump, Brexit, and the Rise of Populism: Economic Have-Nots and Cultural Backlash. Working Paper Series 16-026, John F. Kennedy School of Government, Harvard University.

Jaeger, D. A., Ruist, J., and Stuhler, J. (2018). Shift-share instruments and the impact of immigration. Working Paper 24285, National Bureau of Economic Research.

Jensen, J. B., Quinn, D. P., and Weymouth, S. (2017). Winners and Losers in International Trade: The Effects on US Presidential Voting. International Organization, 71(03):423-457.

Kriesi, H. (2014). The populist challenge. West European Politics, 37(2):361-378.

Kriesi, H., Grande, E., Lachat, R., Dolezal, M., Bornschier, S., and Frey, T. (2006). Globalization and the transformation of the national political space: Six european countries compared. European Journal of Political Research, 45(6):921-956.

Malgouyres, C. (2017). Trade shocks and far-right voting: Evidence from French presidential elections. Research Paper 2017/21, Robert Schuman Centre for Advanced Studies, EUI.

Margalit, Y. (2011). Costly jobs: Trade-related layoffs, government compensation, and voting in u.s. elections. American Political Science Review, 105(1):166-188.

Margalit, Y. (2012). Lost in globalization: International economic integration and the sources of popular discontent. International Studies Quarterly, 56(3):484-500.

Mayda, A. M. (2006). Who is against immigration? a cross-country investigation of individual attitudes toward immigrants. The Review of Economics and Statistics, 88(3):510-530.

Mayda, A. M. and Rodrik, D. (2005). Why are some people (and countries) more protectionist than others? European Economic Review, 49(6):1393-1430.

Montgomery, J. M., Nyhan, B., and Torres, M. (2018). How conditioning on posttreatment variables can ruin your experiment and what to do about it. American Journal of Political Science, 62(3):760-775.

Mudde, C. and Rovira Kaltwasser, C. (2018). Studying populism in comparative perspective: Reflections on the contemporary and future research agenda. Comparative Political Studies, 51(13):1667-1693. 
Nicoli, F. (2017). Hard-line euroscepticism and the eurocrisis: Evidence from a panel study of 108 elections across europe. JCMS: Journal of Common Market Studies, $55(2):-331$.

Otto, A. H. and Steinhardt, M. F. (2014). Immigration and election outcomes - evidence from city districts in hamburg. Regional Science and Urban Economics, 45:67-79.

Rehm, P. (2009). Risks and redistribution: An individual-level analysis. Comparative Political Studies, 42(7):855-881.

Rommel, T. and Walter, S. (2018). The electoral consequences of offshoring: How the globalization of production shapes party preferences. Comparative Political Studies, 51(5):621-658.

Schedler, A. (1996). Anti-political-establishment parties. Party Politics, 2(3):291-312.

Scheve, K. F. and Slaughter, M. J. (2001a). Labor Market Competition And Individual Preferences Over Immigration Policy. The Review of Economics and Statistics, 83(1):133-145.

Scheve, K. F. and Slaughter, M. J. (2001b). What determines individual trade-policy preferences? Journal of International Economics, 54(2):267-292.

Scheve, K. F. and Slaughter, M. J. (2004). Economic insecurity and the globalization of production. American Journal of Political Science, 48(4):662-674.

Schumacher, G. and van Kersbergen, K. (2016). Do mainstream parties adapt to the welfare chauvinism of populist parties? Party Politics, 22(3):300-312.

Stockemer, D. (2015). Structural data on immigration or immigration perceptions? what accounts for the electoral success of the radical right in europe? Journal of Common Market Studies, 54(4):999-1016.

Wacziarg, R. and Welch, K. H. (2008). Trade liberalization and growth: New evidence. World Bank Economic Review, 22(2):187-231.

Walter, S. (2010). Globalization and the welfare state: Testing the microfoundations of the compensation hypothesis. International Studies Quarterly, 54(2):403-426.

Walter, S. (2017). Globalization and the demand-side of politics: How globalization shapes labor market risk perceptions and policy preferences. Political Science Research and Methods, 5(1):55-80.

Wood, A. (2018). The 1990s trade and wages debate in retrospect. The World Economy, 41(4):975-999. 